\title{
THE IMPACT OF THE COVID-19 PANDEMIC ON AUDIOLOGY STUDENTS IN TURKEY: E-LEARNING, KNOWLEDGE OF TELEAUDIOLOGY, PSYCHOLOGICAL AND SOCIAL STATUS AND PERSONAL DEVELOPMENT
}

\author{
Dr. Gul OLCEK \\ ORCID: 0000-0002-2275-5311 \\ Faculty of Health Sciences \\ Istanbul Medipol University \\ Istanbul, TURKEY \\ Ilayda CELIK \\ ORCID: 0000-0003-3796-5300 \\ Faculty of Health Sciences \\ Istanbul Atlas University \\ Istanbul, TURKEY \\ Yusa BASOGLU \\ ORCID: 0000-0002-4771-8824 \\ Faculty of Health Sciences \\ Istanbul Medipol University \\ Istanbul, TURKEY
}

Received: 15/02/2021 Accepted: 24/06/2021

\begin{abstract}
The aim of the study is to examine the different effects of the COVID-19 pandemic on Audiology students in Turkey in terms of e-learning, tele-Audiology education, psychological-social situations and personal development. The study was carried out using an online survey created on Google Forms. The survey included 4 demographic questions, and 29 questions about the effects of COVID-19 on Audiology students. Study sample: A total of 518 undergraduate and graduate Audiology students participated in the study. The majority of the participants indicated that the pandemic had a negative effect on the practical knowledge and professional competence acquired through the online education system implemented due to the restrictions. A great majority of the participants indicated that their theoretical and practical knowledge about teleaudiology was "too insufficient". During this period, the level of anxiety in students and damage to their social relationships were obtained as "too much". In addition, a negative effect was observed in the personal development of the students. The study concluded that strategies and approaches should be developed for the current pandemic period and similar situations that may occur in the future.
\end{abstract}

Keywords: Online education, COVID-19, audiology students, e-learning, tele-audiology.

\section{INTRODUCTION}

In early 2020, after the December 2019 outbreak in China, the World Health Organization identified SARS-CoV-2 as a new type of coronavirus (COVID-19) (Pascarella et al., 2020). The COVID-19 was announced as a pandemic that occurs with severe acute respiratory syndrome and has not been previously identified in humans (Pascarella et al., 2020). Research has shown that person-to-person transmission can occur via direct contact or through droplets spread by coughing or sneezing from an infected individual. All 
countries of the world have taken precautions against this virus, which has no effective treatment and spreads rapidly (Liu et al., 2020).

The first confirmed cases in Turkey of COVID-19 were recorded and declared on March 11, 2020. WHO announced the COVID-19 outbreak as a pandemic on 11 March 2020 and the Turkish government took action with these developments. Thus restrictions, new implementations began in Turkey too ("TR Ministry of Health COVID-19 Information Page", 2020). Restrictions such as distance learning or lockouts began to keep people at home longer and limit movement of the population.

The COVID-19 pandemic has affected the field of education as well as in other areas. In Turkey, as in many countries of the world, options such as various e-learning platforms that enable teachers and students to work and interact together, rapidly developing national Television programs (e.g. TRT EBA TV, where primary, secondary and high school courses are taught from a distance) or lecture videos on social media platforms have started to be implemented ("How Is COVID-19 Affecting Schools in Europe?", 2020).

COVID-19 pandemic rules and restrictions may have led to the increased prevalence of anxiety and depressive symptoms in the general population. Multiple stressors may contribute to increased levels of stress, anxiety, and depressive thoughts among students. A study investigating the Mental Health of College Students showed that the COVID-19 pandemic had negative effects on higher education due to the prolonged pandemic situation and difficult measures such as lockdown and stay-at-home orders (Son, Hegde, Smith, Wang, \& Sasangohar, 2020). Nervousness, frustration, emotional confusion, sadness, exhaustion, boredom, insomnia, inadequate information, poor concentration, indecisiveness, deteriorating work performance, and financial problems are the most common psychological and behavioral reactions in this process (Rogowska, Kuśnierz, \& Bokszczanin, 2020).

Students' attitudes towards distance education are variable. Too many factors lead to these different attitudes. According to one study, although students express positive opinions about distance education, such as being comfortable with computer and internet use, feeling moderately effective and productive, and feeling moderate self-efficacy, they want to return to traditional education (Rizun \& Strzelecki, 2020). This shows us that students struggle to fully adapt to distance education.

Tele-health applications are also seen as a solution in Audiology to reduce the transmission of COVID-19. Audiologists are professionals who provide face-to-face patient care. During this period, one way of providing audiological services to patients was the transition to Tele- Audiology service. The study of Audiologists' opinions on Tele-Audiology services during the COVID-19 pandemic showed that Audiologists generally had a positive experience (Saunders \& Roughley, 2020). However, Audiologists indicated that improvements and training in the system were necessary and they also noted that some hybrid-care pathways should be available as some procedures need to be implemented in person (Saunders \& Roughley, 2020).

Tele-Audiology applications may offer some solutions for limited service delivery capacity, especially during the COVID-19 pandemic (Wootton \& others, 2009). The use of different Tele-Audiology service delivery models (synchronous real-time), asynchronous (store-and-forward), and hybrid models can increase the accessibility of services (Swanepoel et al., 2010). For these reasons, it is important to train Audiology students on Tele-health and Tele-Audiology issues during their education.

The aim of the study is to examine the perspectives of Audiology students on online education, the level of competence of professional skills acquired by e-learning systems, and their psychological, social status and personal development during the COVID-19 pandemic in Turkey. A cross-sectional, self-administered online survey consisting of 7-point Likert-type closed-ended questions was conducted on 518 Audiology students between August 28 and September 30, 2020.

\section{LITERATURE REVIEW}

E-learning seems to be a popular alternative option in the developing world. But the mandatory transition to this new system brought many difficulties both individually and socially in the COVID-19 period. When we examined higher education in the national context in the COVID-19 period, the outstanding problems in Turkey from our perspectives were the 1) readiness of universities for the new system, 2) the knowledge and 
effort of university members, 3) the quality of course content (interactive environment), 4) the arrangement of practice courses and 5) the psychological, social and professional developmental status of students. We focused on these titles when reviewing the literature.

Although we have focused on more superficial problems, studies have shown that there are some problems that continue on a fundamental level. A study examining the perspectives of university students, academicians and teachers in Turkey in online education has revealed the most important supportive and barrier elements in this period. Results showed that the most stated problems were lack of technological resources, internet, appropriate learning environments, and appropriate resources for online education and interaction (Doyumgac, Tanhan \& Kiymaz, 2021). Another study addressed the problems in the infrastructure and education program specific to online audiology education. The study suggested that universities, faculty members and students may have different technological infrastructure, and in order to increase the quality of audiology education, it is important to eliminate this inequality and to make updates in audiology education programs by considering online education systems (Gokdogan \& Genc, 2020). In the literature, many different challenges have been mentioned in studies related to e-learning, but infrastructure problems come to the fore especially in developing countries. For example, a study conducted in Pakistan showed that $76 \%$ of 382 students use mobile tools for e-learning. $77.4 \%$ of the students showed a negative perception about e-learning and $86 \%$ of them thought that e-learning had little effect on their learning. The vast majority of students preferred face-to-face teaching over e-learning (Abbasi, Ayoob, Malik, \& Memon, 2020). But in countries where access conditions are better, online education is becoming more accepted, while problems focus more on education content and personal situations. Michał Baczek, et al. investigated medical students' perception of online learning during the COVID-19 outbreak. According to the responses of the respondents, the main advantages of online learning were staying at home (69\%), constant access to online materials (69\%), self-paced learning (64\%) and a relaxed environment (54\%). Most of the respondents chose the lack of interaction with patients $(70 \%)$ and technical problems with IT equipment (54\%) as the main disadvantages. They showed in their research that there was no statistically significant difference between face-to-face and distance education in terms of views on the learning method's ability to increase knowledge (Baczek, Zaganczyk-Baczek, Szpringer, Jaroszynski, \& Wożakowska-Kapłon, 2021). In addition, they found that students were statistically less active in online lessons compared to traditional lessons (Baczek, Zaganczyk-Baczek, Szpringer, Jaroszynski, \& Wożakowska-Kapłon, 2021).

Also, before COVID-19, online learning was a popular option due to its flexibility and customized online programs to students' needs (Richardson, Maeda, Lv \& Caskurlu, 2017). But the immediate transition to online education with the COVID-19 crisis has led to shortcomings in the content and adequacy of education. In this regard, the adequacy of educators, the adequacy of online materials and the flexibility of platforms are important factors. A study related to emergency distance learning experience showed the importance of readiness of teachers and students for emergency learning, using blended materials, designing the new curriculum that meets needs, developing new learning skills, and providing access to digital materials (Rahiem, 2020). A study examining medical students' acceptance and perceptions of e-learning during Covid-19 showed a moderate acceptance of e-learning. However, the results suggested that there is a need for more training in the use of the system, better organized online courses, more teacher-student interaction and motivation, and mixed learning (Ibrahim et al., 2021). Blended learning methods and efforts of university members for effective learning are especially important in departments with practical courses. In addition, interactive participation and motivation are important for students' capacity to stay mentally engaged in e-learning. A study conducted with students from the Philippines highlighted the difficulties in this period of online learning as learning style changes, other mandatory responsibilities at home, and poor communication / interaction between educator and student (Baticulon et al., 2021). They emphasized the importance of student-centered approaches and efforts of school management and educators on this point.

Beyond technical and learning problems, the asynchronous nature of e-learning and communication problems can reveal problems in the context of social existence for students after being isolated from the social environment for a long time with quarantines (Händel et al., 2020; Richardson, Maeda, Lv \& Caskurlu, 2017). Thus, limited social interaction due to COVID-19 can lead to negative emotions, and social isolation can lead to stress-related emotions in students (Beaunoyer, Dupere, \& Guitton, 2020; Miller, 2020). It is clear that the COVID-19 pandemic has significant effects on the mental health, education, and daily life of 
students (Chaturvedi, Vishwakarma, \& Singh, 2021). Measures should be taken not only for the quality of education but also for the mental health and social life of the students, and thus learning experiences should be improved (Chaturvedi, Vishwakarma, \& Singh, 2021).

The COVID-19 outbreak has also accelerated some changes in the field of audiology. Tele-Audiology services, which are included in the Tele-health services that allow for remote service delivery, have gained importance in this process. For example, the continuity of rehabilitation, which is crucial for the development of language and speech after amplification for children with hearing loss, is possible with tele-intervention applications (Altinyay, 2020). ASHA conducted a survey on the use of tele-practice and tele-audiology services in the pandemic period. It showed that only $9.6 \%$ of faculty and clinical instructors routinely provided clinical services through telepractice prior to COVID-19, but more than $60 \%$ now routinely provide services through telepractice (Volkers, 2020). That's why it is important that the audiology education program includes theoretical and practical courses of tele-Audiology services.

In 2015, ASHA found that only a quarter of the graduate audiology programs in the United States provided any educational service in telepractice (Grogan-Johnson, Meehan, McCormick, \& Miller, 2015). Mohan et al. researched the use of telepractice in speech-language pathologists and audiologists in India. Two hundred and five $(\mathrm{N}=205)$ speech-language pathologists and audiologists responded to the questionnaire, and only $12.19 \%$ of the participants reported using telepractice to provide clinical services (Mohan, Anjum, \& Rao, 2017). In the current situation, many clinicians had to rapidly change their service methods from face-toface to remote telepractice. Many clinicians have had to adapt their evaluation and treatment programs according to the needs of the patients without prior experience in this method. Therefore, it is essential for future audiologists to have a tele-audiology services course in audiology education and to establish the necessary infrastructure.

\section{METHOD}

\section{Participants}

The study was performed between August 28 and September 30, 2020 in Turkey. The research was carried out using an online survey created on Google Forms. Data were collected according to the spring semester of 2020 when restrictions were most intense. In the first stage, the survey questions were prepared regarding the questions and opinions of the representative audiology students from each class and 4 academicians of the audiology department about the pandemic period. Later, we completed the survey arrangements, considering the guidelines of COVID-19 related associations such as the American Speech-LanguageHearing Association (ASHA) (ASHA, 2020) (Figure 1). The survey included 4 demographic questions and 29 items about the effects of COVID-19 on Audiology students. The survey consists of three parts: the first part aimed to collect demographic information, while the second part (first/common section) aimed to collect information about effects of the COVID-19 pandemic on e-learning, tele-Audiology, psychological and social state and personal development. The third part (second/specific section) aimed to collect data on whether the graduate students (4th grade students in the 2020 spring semester) reached their career goals, and whether they could find the job opportunities they desired. Detailed explanations about the purpose of the study, information about researchers and the voluntary informed consent form were placed on the first page. Participation in the survey was completely voluntarily, and the informed consent form was marked by all participants. After marking the consent form and declaring the acceptance of participation, the main questions were seen.

\section{Data Collection and Analysis}

We reached out to the participants through social media accounts (Instagram, WhatsApp, etc.) and virtual meeting programs (Zoom Meeting, Microsoft Teams, etc.) that Audiology students subscribed to or followed (snowball sampling). The survey was completed in approximately 10 minutes. A seven-point likert-type scale was used to allow the participants to indicate how much they felt a level of competence with a specific statement and how much it affected their specific situations during this period. So, two numerical scales 
with 7 points were used in the study. The first scale, where 1 is "too insufficient" and 7 is "very sufficient", refers to participants' level of competence (1: too insufficient 2: insufficient 3: somewhat insufficient 4: neutral 5: somewhat sufficient 6: sufficient 7: very sufficient). The second scale, where 1 is "not at all" and 7 is "too much", refers to the impact amount of the pandemic period on participants (1: not at all, 2: too little, 3: little, 4: neither less nor more, 5: a bit much, 6: much, 7: too much). The aim of the study is to examine the perspectives of Audiology students on online education, the level of competence of professional skills acquired by e-learning systems, and their psychological, social status and personal development during the COVID-19 pandemic in Turkey. For this purpose, we formulated the following research questions: 1) What is the educational satisfaction and content of the online education system, which started with the COVID-19 pandemic compared to the traditional (face-to-face education) system? 2) What competence do Audiology students see in themselves regarding distance healthcare (e.g. Tele-Audiology) services, which have become more important with the COVID-19 pandemic? 3) What is the psychological and social impact of the changing living conditions with the COVID-19 pandemic on Audiology students? 4) What are the effects of the distance education system that started with the COVID-19 pandemic and the orders to stay home for a long time on the personal and professional development of Audiology students? 5) After the distance education system that started with the COVID-19 pandemic, is there any difference in terms of educational content, educational satisfaction, Tele-Audiology competence, psychological-social status and personal development by gender, class degree and university? 6) What is the status of professional development and job access of newly graduated audiologists who graduated with the distance education system and other challenging conditions brought about by the COVID-19 pandemic in the last educational period of the Bachelor's Degree? The following hypotheses were formulated:

1) In previous studies conducted in health departments requiring clinical practice, such as audiology, it has been observed that the distance education system is insufficient in terms of acquiring clinical practice and technical skills, and satisfaction is low. (Abbasi et al., 2020; Wang, Xie, Wang, \& Wu, 2020). We hypothesize that the distance education system will be found insufficient in many aspects for audiology students. 2) Many previous studies have shown that although audiologists have good attitudes towards tele-audiology, few of them apply to the clinic and there is a lack of infrastructure and education (Saunders \& Roughley, 2020; Eikelboom \& Swanepoel, 2016). We hypothesize that audiology students will feel theoretically and practically inadequate in tele-audiology due to the gaps in education. 3) Studies on the mental health of university students during the COVID-19 period have shown that many factors such as financial constraints, distance online education and uncertainty about the future affect students psychologically (Rogowska, Kuśnierz, \& Bokszczanin, 2020; Sundarasen et al., 2020). It is also predicted that loneliness and isolation will increase as a result of the mentioned situations in this period (Araujo, de Lima, Cidade, Nobre, \& Neto, 2020; Elmer, Mepham, \& Stadtfeld, 2020). In our study, we hypothesize that the COVID-19 pandemic will cause psychological and social effects in audiology students due to changing living and educational conditions. 4) Research has shown that university students faced many difficulties such as changing environmental conditions, prolonged lockdown, lack of social activities, increasing school workload, difficulty in participating in online activities, and inability to manage time (Son, Hegde, Smith, Wang, \& Sasangohar, 2020). We hypothesize that the personal and professional development of university students will be negatively affected, especially in relation to these situations. 5) Based on previous research, we assume that female students will be more psychologically affected by this process (AlAteeq, Aljhani, \& AlEesa, 2020; Browning et al., 2021; Zolotov, Reznik, Bender, \& Isralowitz, 2020). We expect that there will be no gender difference, for other subheadings. 6) According to recent studies, senior students faced problems such as self-confidence, readiness, and achieving the job they wanted (Choi et al., 2020; Akkermans, Richardson, $\&$ Kraimer, 2020). We hypothesize that newly graduated audiologists will experience the negative effects of having graduated during the COVID-19 pandemic. The findings of this study may support further intervention and efficient prevention programs at universities. 


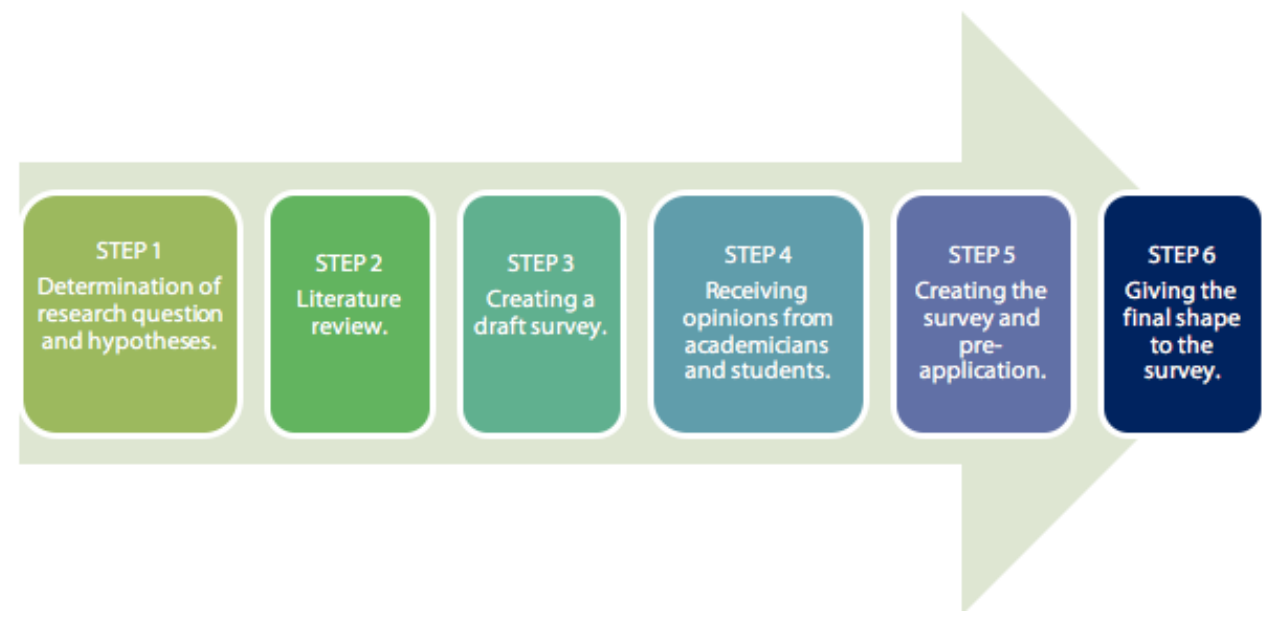

Figure 1. Survey development process

The criterion for inclusion in the study was to be an Audiology undergraduate or graduate student. Each participant had to sign-in to their Google account to participate in the survey. Thus, each participant was able to answer the survey once. Descriptive statistics were used, including mean values, standard deviation, frequency and percentage. The Mann Whitney $U$ test was used to compare gender differences. The Kruskal Wallis test was used to determine whether there was a statistically significant difference between class degrees. The Bonferroni correction, which is in the post-hoc test group, was used to investigate the significance between class degrees. All analysis was done using the IBM SPSS 22.0 version program.

\section{Validity of the Survey}

The reliability of the survey was evaluated by Cronbach's alpha, where the sufficiency level for the alpha coefficient is $\geq 0.70$ (Cortina, 1993). In this research, Cronbach's alpha coefficient for the whole survey was 0.83 , which shows good internal consistency. Moreover, Cronbach's alpha value for "E-learning, TeleAudiology, psychological and social status and personal development" subscales was found to be $0.93,0.89$, 0.81 and 0.73 respectively.

\section{FINDINGS}

518 undergraduate and graduate students who study at the Audiology department at universities in Turkey participated in our survey in the spring semester of 2020. The respondents of this survey were undergraduate (97.3\%) and graduate students (2.7\%) from public (29\%) and private (71\%) universities in Turkey, and Table 1 shows the descriptive statistics of the demographic characteristics of participants. Demographic information consists of gender, class degree, university type (private / public) and residency area (province / district / rural). 
Table 1. Demographic Information

\begin{tabular}{cl}
\hline DEMOGRAPHIC INFORMATION & THE NUMBER OF PARTICIPANTS (N=518) \\
\hline Gender & $\mathbf{N}(\%)$ \\
\hline Female & $452(86,9 \%)$ \\
Male & $66(13,1 \%)$ \\
\hline University & $\mathbf{N}(\%)$ \\
\hline Public University & $150(29 \%)$ \\
Private University & $368(71 \%)$ \\
\hline Reside area & $\mathbf{N}(\%)$ \\
\hline Province & $305(58,9 \%)$ \\
District & $179(34,6 \%)$ \\
Rural & $34(6,6 \%)$ \\
\hline Class degree & $\mathbf{N}(\%)$ \\
\hline First Grade Student & $145(28 \%)$ \\
Sophomore & $150(29 \%)$ \\
Third Grade Student & $142(27,4 \%)$ \\
Fourth Grade Student & $67(12,9 \%)$ \\
Graduate Student & $14(2,7 \%)$ \\
\hline
\end{tabular}

The results are shown in the first section of Table 2 about online education systems, online education qualification and knowledge of Tele-Audiology service. Also, the first section includes results about psychological, social state and personal development and career goals of Audiology students during the COVID-19 pandemic period.

The special question, Q17, asked about the precautions to be applied in the clinic during the pandemic period, to which most of the students (21.2\%) responded as "somewhat insufficient".

In the second section of Table 2, there are questions for only 4th grade students, from Q26 to Q29. We asked how much recently graduated Audiologists who graduated with distance education systems, due to the quarantine brought by the COVID-19 pandemic, achieved their career goals and their desired job. In addition, it was asked whether new graduates from the Department of Audiology within the healthcare professional group had sufficient knowledge of COVID-19 rules (wearing masks, complying with social distance, hygiene rules). The results of $47.8 \%$ of students for Q27 were obtained as "very sufficient". Results of the Q26, Q28 and Q29 about career goals, job opportunities and professional competence were obtained as "neutral" with $28.4 \%$, "somewhat sufficient" with $34.3 \%$ and "neutral" with $28.4 \%$ respectively.

Furthermore, comparison results depending on $\mathrm{p}$ value are given in gender and class degree in Table 2. A significant difference was obtained in Q8 and Q20 depending on gender. Also, a significant difference was obtained in the questions of Q1-7, Q13-19, and Q21 depending on the class degree.

\section{E-learning System}

The first section (from Q1 to Q14) includes questions about e-learning. Students were questioned on issues such as adaptation to the online system, sustaining the attention, and the competency of e-learning in knowledge acquisition and competence of academic staff. Q4, which examines the relationship between online education and attention, it was observed that $19.7 \%$ of the students answered "insufficient" and $21.4 \%$ answered "somewhat insufficient", respectively. . The restriction of face-to-face practical courses and internships also affected the acquisition of professional knowledge in this process and this was questioned in Q7. The answers of the students to the level of professional knowledge they have acquired through the 
online practical courses are given in Figure 2. In our study, besides the system, academicians' attitudes and students' perceptions on academic work were also questioned. For Q8, students responded in close proportions for 7 options on the likert-type scale and the result was obtained as "somewhat sufficient" with $16.4 \%$. According to the statistically significant difference obtained by gender in Q8, the results of the females were obtained as more insufficient than the results of the males. Q9 was obtained as "sufficient" with $22.8 \%$. Approximately one in three students (29.7\%) responded to Q10 as "somewhat sufficient". Q13 was mostly found to be "somewhat sufficient" with $24.5 \%$. In Table 2, it was observed that especially the results of Q7 were remarkable and $26.6 \%$ of the students answered as "too insufficient" and $20.7 \%$ of them answered as "insufficient", respectively. In addition, another remarkable finding was that $38.6 \%$ of the students answered "too insufficient" to Q14. The answers of the students to Q14 is given in Figure 3. The overall satisfaction of students who made an unexpected transition to e-learning was questioned with Q25. The result was obtained as "neutral" with $23.9 \%$.

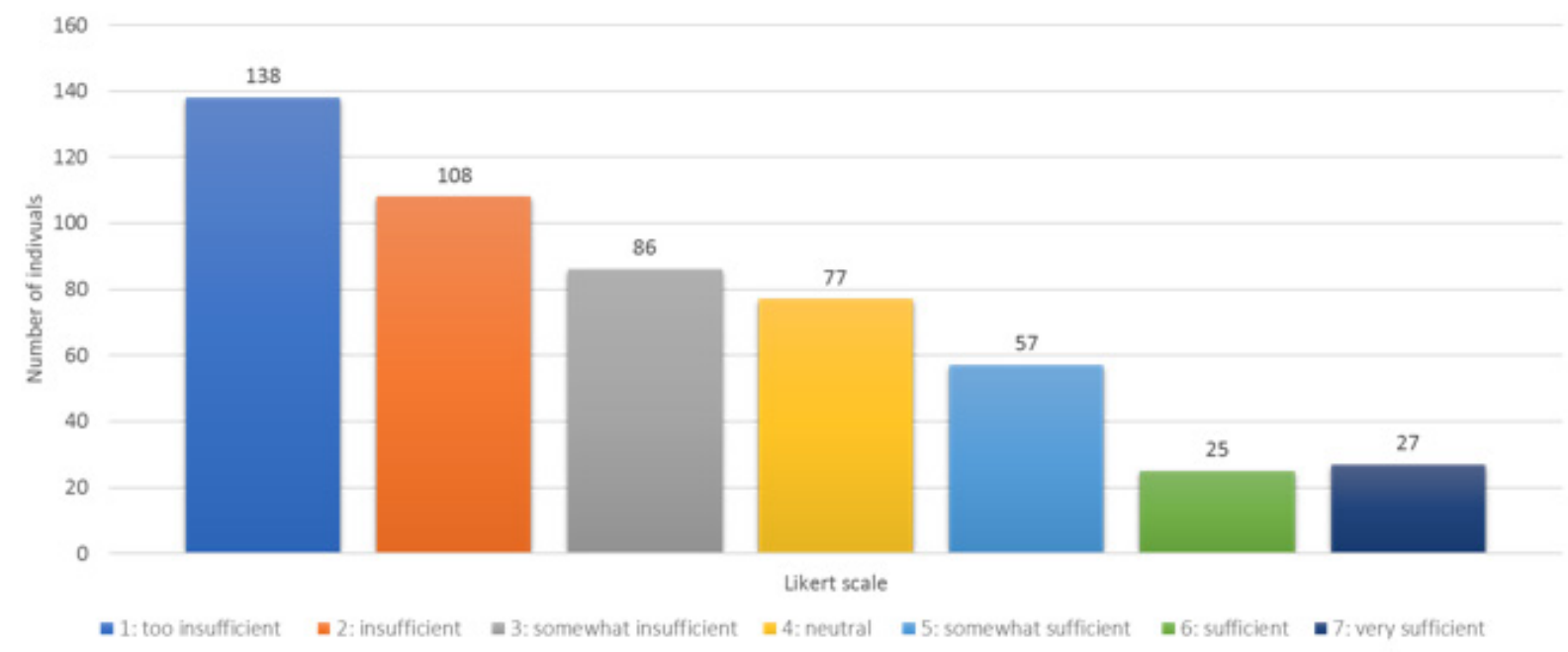

Figure 2. Answers to the Q7 (Q7: Please select the level of professional knowledge you have acquired)

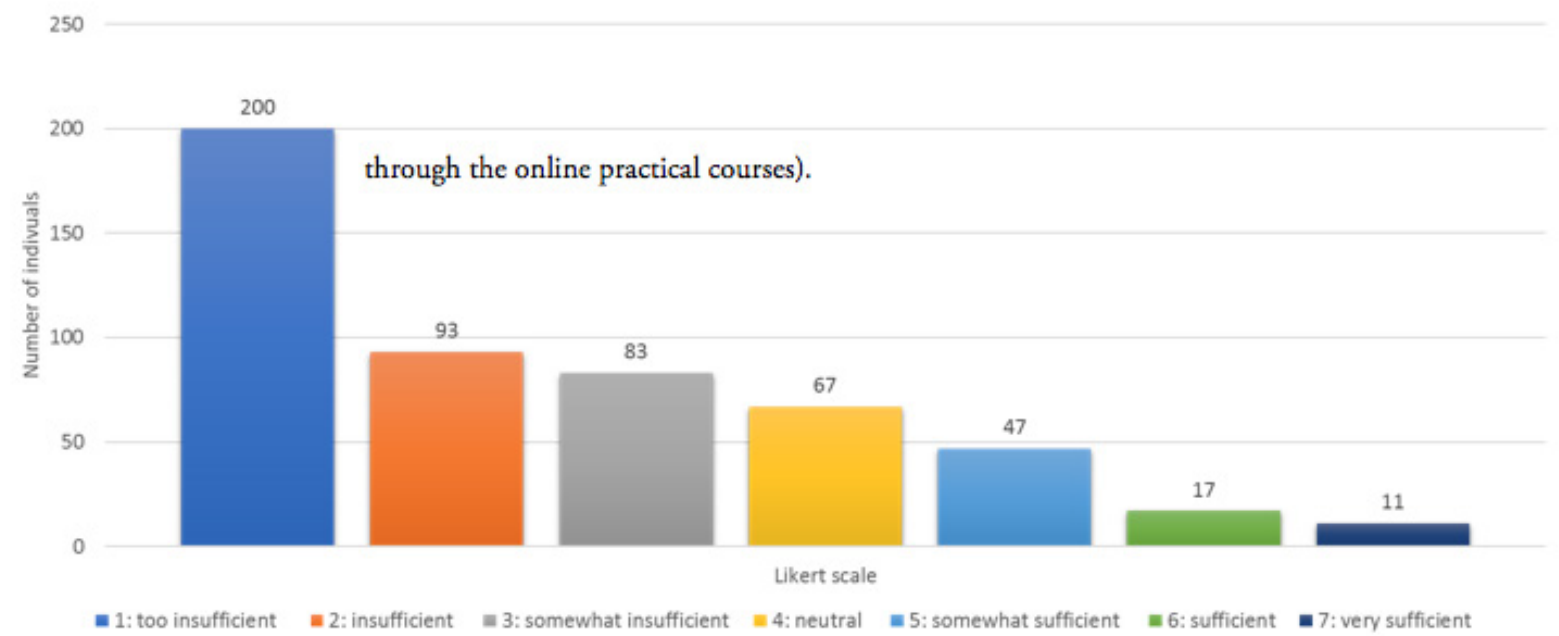

Figure 3. Answers to the Q14 (Q14: Please select your level of readiness to internship/ work as Audiologist before the practical courses are completed). 


\section{Tele-Audiology}

Students' level of knowledge in Tele-Audiology and their competence in practice was questioned in Q18 and Q19. In addition, the answers given by the students to Q18 and Q19 are given in Figures 4 and 5. $26.6 \%$ and $33.4 \%$ of the students answered "too insufficient" to Q18 and Q19, respectively. A statistically significant difference was found between the class degrees in these questions. In both questions, it was observed that the responses of graduate students were more positive than undergraduate students.

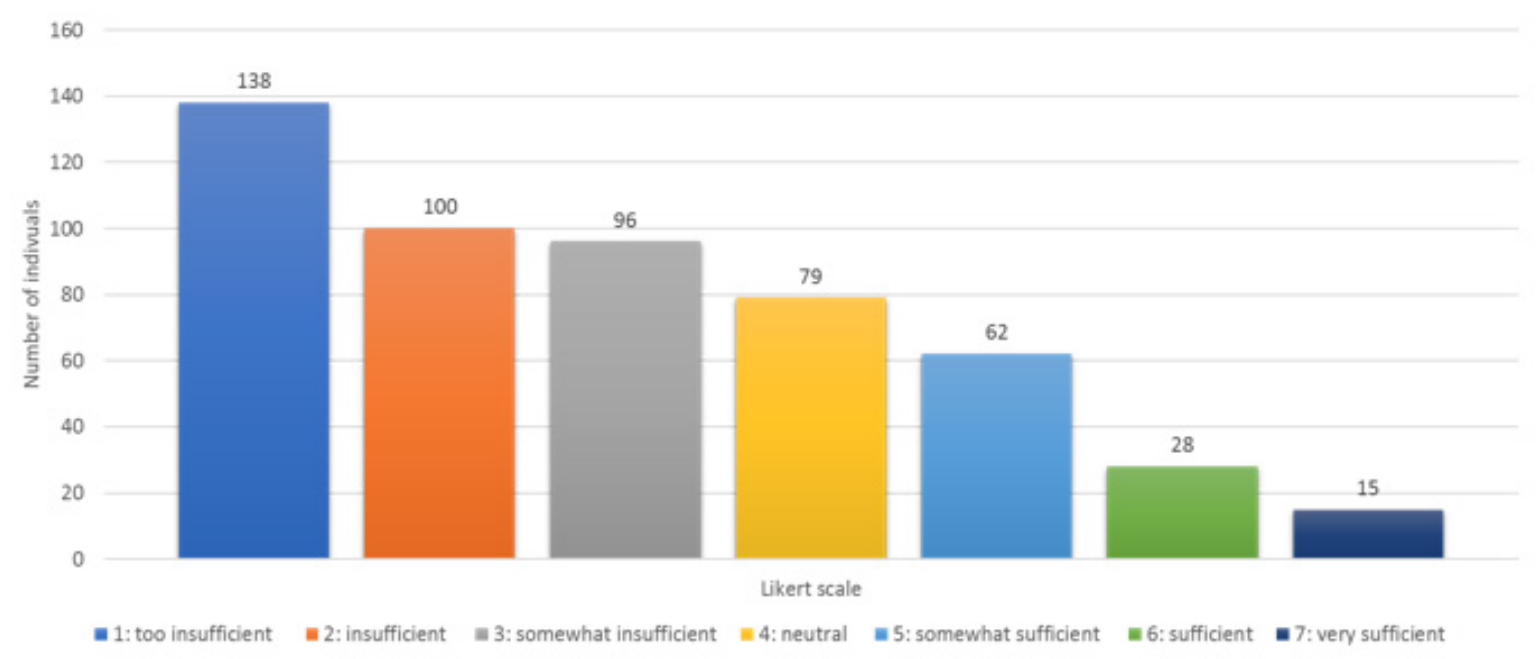

Figure 4. Answers to the Q18 (Q18: Please, select your level of theoretical knowledge about teleAudiology services.).

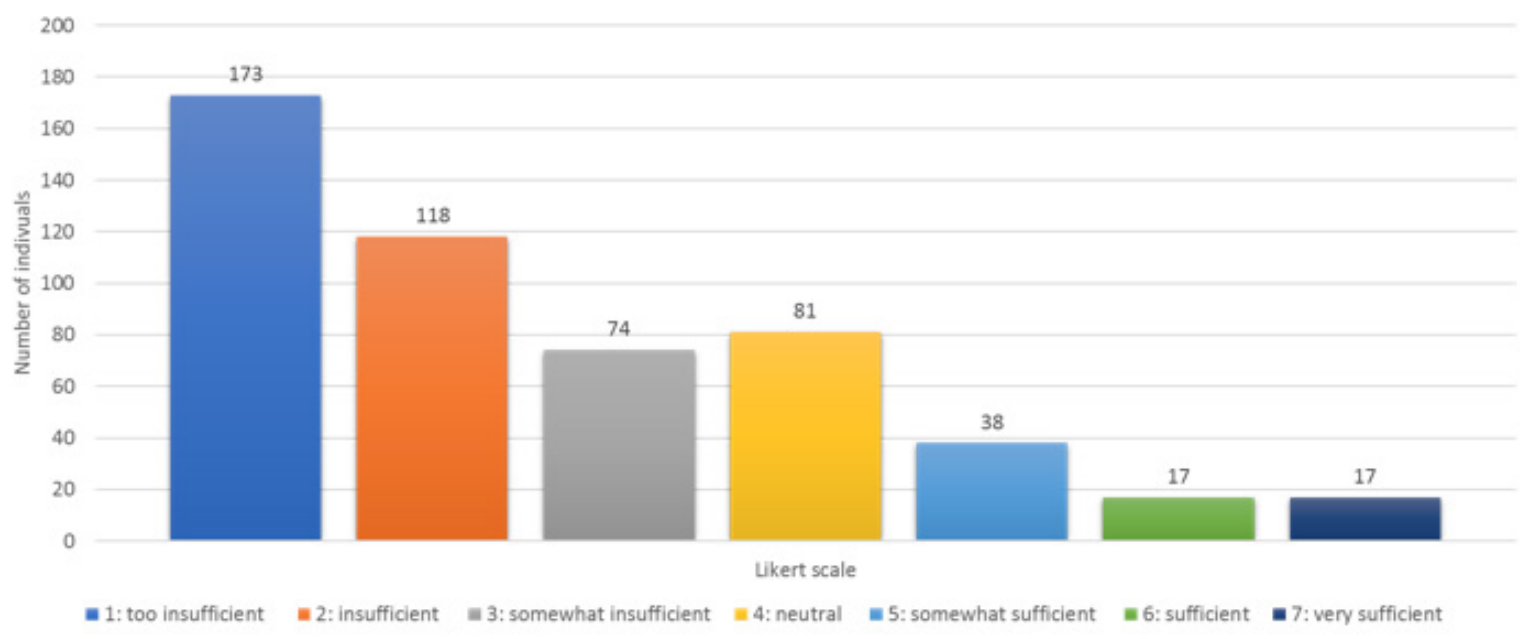

Figure 5. Answers to the Q19 (Q19: Please, select your level of practical competence regarding teleAudiology services).

\section{Psychological and Social Status}

Questions from 20 to 22 were about the psychological, and social state of Audiology students during the COVID-19 pandemic period. According to the survey, students were negatively affected emotionally and psychologically during the pandemic period. The level of anxiety that occurred during the pandemic period was found to be "much". The answers given by the students to Q20 is given in Figure 5. A statistically significant difference was obtained in terms of gender in Q20. Results showed that female students experienced more anxiety than male students during the COVID-19 period. For the Q20, 35\% of the 
students answered as "too much". In Q21, a statistically significant difference was found in the comparison between classes. Fourth grade students responded on average higher than other class degrees for Q21. In Q22, the level of negative impact of the pandemic on the students' social relationships was obtained as "too much" with $28 \%$. The answers given by the students to Q22 is given in Figure 7.

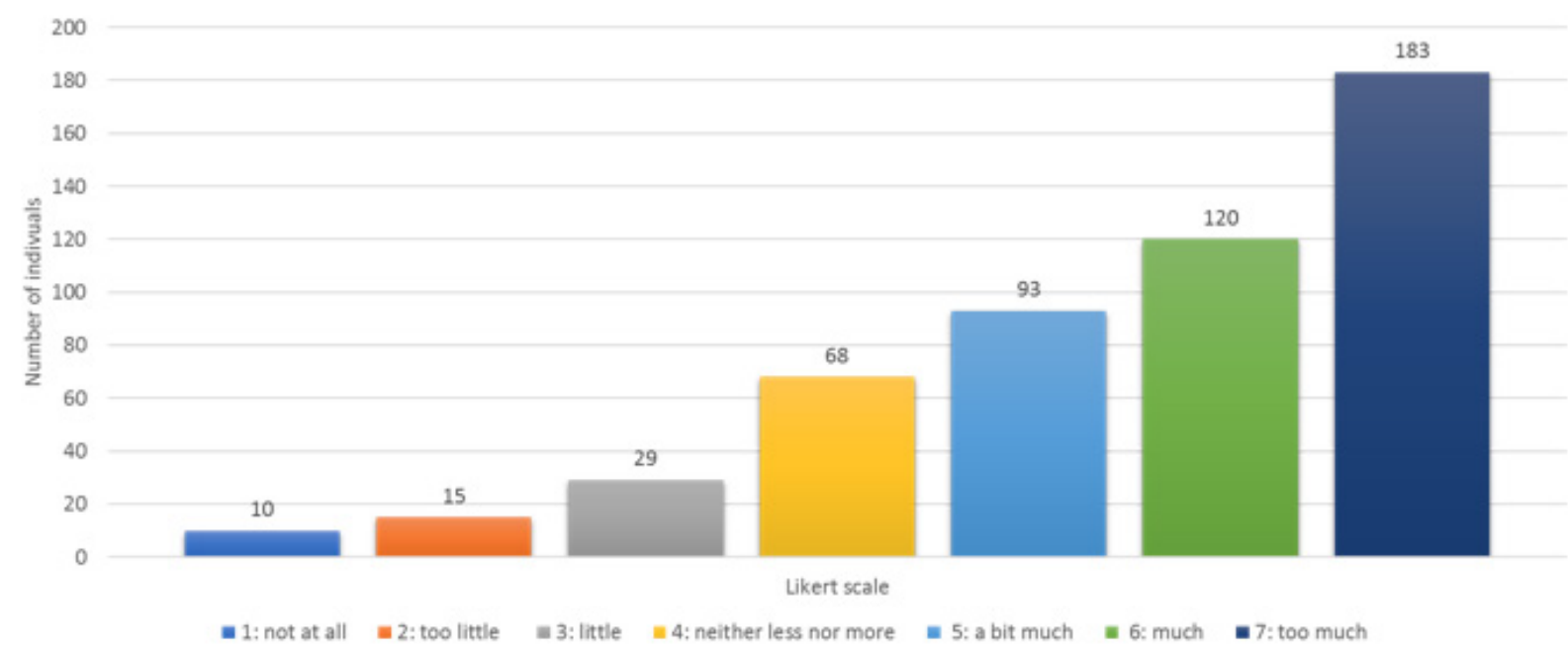

Figure 6. Answers to the Q20 (Q20: Please, select your level of anxiety that occurred with the pandemic).

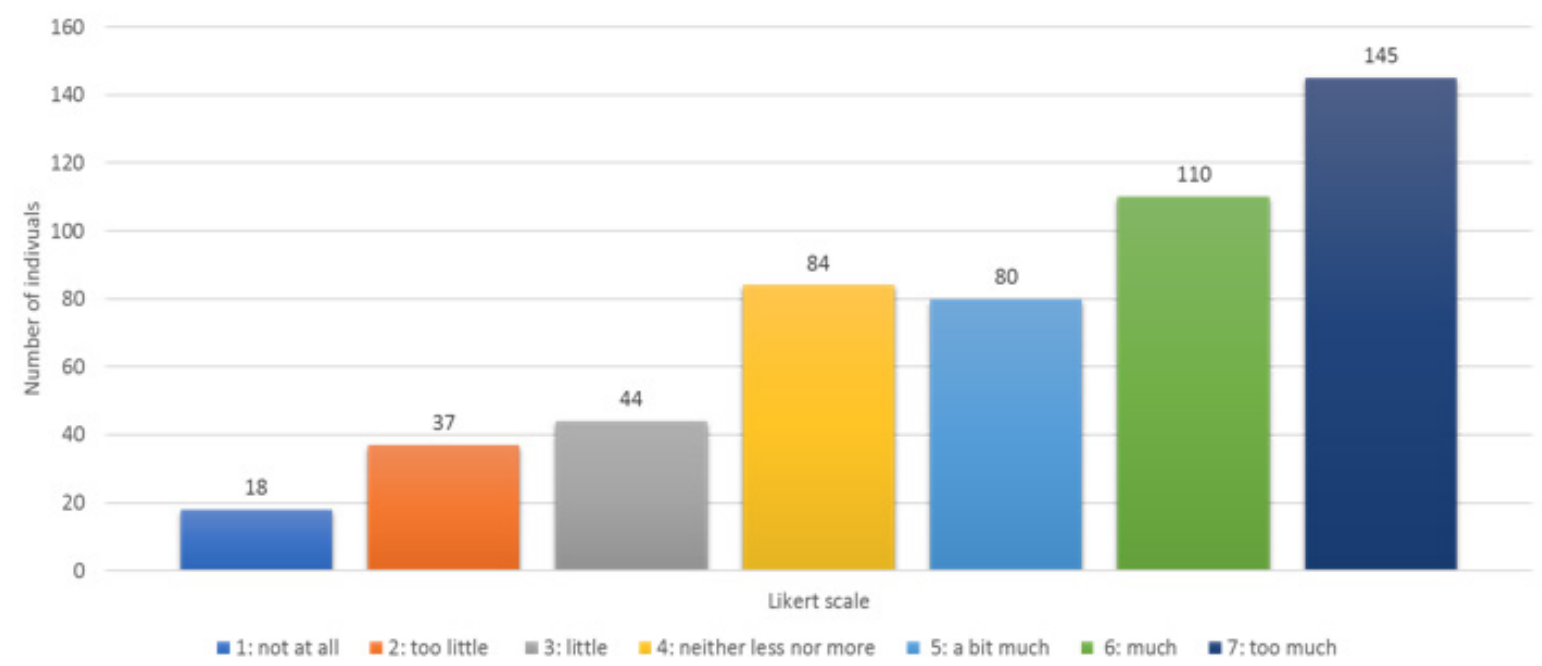

Figure 7. Answers to the Q22 (Q22: Please, select to what extent the pandemic process has negatively affected your social relationships).

\section{Personal Development}

Q15, Q16, Q23 and Q24 examine the effects of COVID-19 on the students' personal and professional development as a result of stay-at-home orders and the e-learning system. For Q15, 22.4\% of the participants answered as "insufficient". For Q16 and Q23, 21.7\% of students and 25.7\%, respectively, answered as "neutral". It has been observed that the effect of the pandemic period on students' orientation and career goals, in Q24, was mostly (22.6\%) "a bit much". A statistical difference was observed between the classes only in Q15 and Q16. 
Table 2. Online survey descriptive statistics.

\begin{tabular}{|c|c|c|c|c|c|c|c|c|}
\hline Item & $\begin{array}{l}\text { FIRST SECTION } \\
\text { Questions (about } \\
\text { online education } \\
\text { system, distance } \\
\text { education } \\
\text { qualification and } \\
\text { Tele-Audiology } \\
\text { service knowledge of } \\
\text { Audiology students } \\
\text { during the COVID-19 } \\
\text { pandemic period) }\end{array}$ & $\mathbf{N}$ & $\begin{array}{l}\text { Mean } \pm \text { Std. } \\
\text { Deviation } \\
\text { (Min:1, too } \\
\text { insufficient; } \\
\text { Max:7, very } \\
\text { sufficient) }\end{array}$ & $\begin{array}{l}\begin{array}{l}\text { Frequency } \\
\text { and Percent- } \\
\text { ages }\end{array} \\
\text { (Min:1, too } \\
\text { insufficient; } \\
\text { Max:7, very } \\
\text { sufficient) }\end{array}$ & $\begin{array}{l}\text { Gender } \\
\text { (Mean } \pm \text { Std. } \\
\text { Deviation) }\end{array}$ & $\begin{array}{l}\text { P } \\
\text { Value }\end{array}$ & $\begin{array}{l}\text { Class Degree } \\
\text { (1: First Grade, } \\
\text { 2: Second Grade, } \\
\text { 3: Third Grade, } \\
\text { 4: Fourth Grade, } \\
\text { GS: Graduate } \\
\text { Student; Mean } \pm \\
\text { Std. Deviation) }\end{array}$ & $\begin{array}{l}P \\
\text { Value }\end{array}$ \\
\hline Q1 & $\begin{array}{l}\text { Please select the level } \\
\text { of competence of } \\
\text { technical equipment } \\
\text { required for online } \\
\text { education. }\end{array}$ & 518 & $5,10 \pm 1,62$ & $\begin{array}{l}\text { 1: } 13(2,5 \%) \\
\text { 2: } 26(5 \%) \\
\text { 3:58 (11\%) } \\
\text { 4: } 67(12,9 \%) \\
\text { 5: } 119(23 \%) \\
\text { 6: } 106(20,5 \%) \\
\text { 7: } 129(24,9 \%)\end{array}$ & $\begin{array}{l}\text { Female:5,13 } \\
1,59 \\
\text { Male: } 4,86 \pm 1,80\end{array}$ & 0.33 & $\begin{array}{l}1: 5,05 \pm 1,72 \\
2: 4,90 \pm 1,50 \\
3: 5,07 \pm 1,65 \\
4: 5,52 \pm 1,64 \\
G S: 6,00 \pm 0,78\end{array}$ & 更 \\
\hline Q2 & $\begin{array}{l}\text { Please select your } \\
\text { comfort level in using } \\
\text { the online education } \\
\text { platform. }\end{array}$ & 518 & $4,79 \pm 1,65$ & $\begin{array}{l}\text { 1: } 21(4,1 \%) \\
\text { 2: } 31(6 \%) \\
\text { 3: } 63(12,2 \%) \\
\text { 4: } 93(18 \%) \\
\text { 5: } 116(22,4 \%) \\
\text { 6: } 103(19,9 \%) \\
\text { 7: } 91(17,6 \%)\end{array}$ & $\begin{array}{l}\text { Female: } \\
4,84 \pm 1,60 \\
\text { Male: } 4,39 \pm 1,86\end{array}$ & 0.74 & 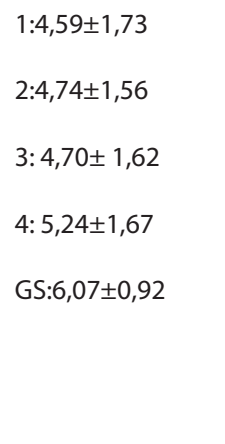 & $0.00^{* *}$ \\
\hline Q3 & $\begin{array}{l}\text { Please select the level } \\
\text { of your adaptation } \\
\text { time to online } \\
\text { education. }\end{array}$ & 518 & $3,95 \pm 1,71$ & $\begin{array}{l}\text { 1: } 49(9,5 \%) \\
\text { 2: } 65(12,5 \%) \\
\text { 3: } 94(18,1 \%) \\
\text { 4: } 112(21,6 \%) \\
\text { 5: } 99(19,1 \%) \\
\text { 6: } 53(10,29 \%) \\
\text { 7: } 46(8,9 \%)\end{array}$ & $\begin{array}{l}\text { Female: } \\
3,97 \pm 1,67 \\
\text { Male: } 3,76 \pm 1,97\end{array}$ & 0.42 & $\begin{array}{l}1: 3,79 \pm 1,84 \\
2: 3,82 \pm 1,54 \\
3: 3,76 \pm 1,63 \\
4: 4,70 \pm 1,78 \\
\text { GS: } 5,14 \pm 1,29\end{array}$ & . \\
\hline Q4 & $\begin{array}{l}\text { Please select the } \\
\text { level of your ability to } \\
\text { sustain your interest/ } \\
\text { attention to the } \\
\text { lessons with online } \\
\text { education. }\end{array}$ & 518 & $3,39 \pm 1,73$ & $\begin{array}{l}\text { 1: } 79(15,3 \%) \\
\text { 2: } 102(19,7 \%) \\
\text { 3: } 111(21,4 \%) \\
\text { 4: } 92(17,8 \%) \\
\text { 5: } 64(12,4 \%) \\
\text { 6: } 36(6,9 \%) \\
\text { 7: } 34(6,6 \%)\end{array}$ & $\begin{array}{l}\text { Female: } \\
3,38 \pm 1,69\end{array}$ & 0.94 & $\begin{array}{l}1: 3,95 \pm 1,71 \\
2: 3,29 \pm 1,80 \\
3: 3,35 \pm 1,69 \\
4: 3,09 \pm 1,64 \\
G S: 4,16 \pm 1,76\end{array}$ & $0.00^{* *}$ \\
\hline
\end{tabular}




\begin{tabular}{|c|c|c|c|c|c|c|c|c|}
\hline Q5 & $\begin{array}{l}\text { Please select your } \\
\text { level of interactive } \\
\text { participation in online } \\
\text { education. }\end{array}$ & 518 & $3,72 \pm 1,82$ & $\begin{array}{l}\text { 1: } 78(15,1 \%) \\
\text { 2: } 69(13,3 \%) \\
\text { 3: } 91(17,6 \%) \\
\text { 4: } 108(20,8 \%) \\
\text { 5: } 72(13,9 \%) \\
\text { 6: } 56(10,8 \%) \\
\text { 7: } 55(8,5 \%)\end{array}$ & $\begin{array}{l}\text { Female: } \\
3,74+1,81 \\
\text { Male: } 3,51 \pm 1,85\end{array}$ & 0,38 & $\begin{array}{l}1: 3,79 \pm 1,78 \\
2: 3,67 \pm 1,79 \\
3: 3,30 \pm 1,87 \\
4: 4,40 \pm 1,76 \\
\text { GS: } 4,43 \pm 1,40\end{array}$ & . \\
\hline Q6 & $\begin{array}{l}\text { Please select the } \\
\text { level of professional } \\
\text { knowledge you have } \\
\text { acquired through the } \\
\text { online theoretical } \\
\text { courses. }\end{array}$ & 518 & $3,47 \pm 1,73$ & $\begin{array}{l}\text { 1: } 84(16,2 \%) \\
\text { 2: } 84(16,2 \%) \\
\text { 3:103 (19,9\%) } \\
\text { 4: } 100(19,3 \%) \\
\text { 5: } 74(14,3 \%) \\
\text { 6: } 46(8,9 \%) \\
\text { 7: } 27(5,2 \%)\end{array}$ & $\begin{array}{l}\text { Female: } \\
3,48 \pm 1,70 \\
\text { Male: } 3,36 \pm 1,90\end{array}$ & . & $\begin{array}{l}1: 3,72 \pm 1,82 \\
2: 3,24 \pm 1,87 \\
3: 3,46 \pm 1,63 \\
4: 3,32 \pm 1,65 \\
\text { GS: } 4,03 \pm 1,77\end{array}$ & 更 \\
\hline Q7 & $\begin{array}{l}\text { Please select the } \\
\text { level of professional } \\
\text { knowledge you have } \\
\text { acquired through } \\
\text { the online practical } \\
\text { courses. }\end{array}$ & 518 & $2,98 \pm 1,77$ & $\begin{array}{l}\text { 1:138 (26,6\%) } \\
\text { 2: } 108(20,8 \%) \\
\text { 3: } 86(16,6 \%) \\
\text { 4: } 77(14,9 \%) \\
\text { 5: } 57(11 \%) \\
\text { 6: } 25(4,8 \%) \\
\text { 7: } 27(5,2 \%)\end{array}$ & $\begin{array}{l}\text { Female: } \\
2.94 \pm 1,72 \\
\text { Male: } 3,22 \pm 2,02\end{array}$ & . & $\begin{array}{l}1: 2,88 \pm 1,92 \\
2: 2,83 \pm 1,61 \\
3: 2,77 \pm 1,63 \\
4: 3,70 \pm 1,89 \\
\text { GS:4,21 } \pm 1,42\end{array}$ & 更 \\
\hline Q8 & $\begin{array}{l}\text { Please select the } \\
\text { adequacy of the } \\
\text { exams in the form of } \\
\text { homework in terms of } \\
\text { the education system. }\end{array}$ & 518 & $3,90 \pm 1,93$ & $\begin{array}{l}\text { 1: } 76(14,7 \%) \\
\text { 2: } 70(13,5 \%) \\
\text { 3: } 79(15,3 \%) \\
\text { 4: } 82(15,8 \%) \\
\text { 5: } 85(16,4 \%) \\
\text { 6:68 (13,1\%) } \\
\text { 7: } 58(11,2 \%)\end{array}$ & $\begin{array}{l}\text { Female: } \\
3,82 \pm 1,90 \\
\text { Male: } 4,39 \pm 2,00\end{array}$ & . & 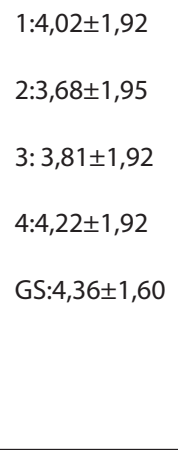 & 更 \\
\hline Q9 & $\begin{array}{l}\text { Please select the } \\
\text { level of getting } \\
\text { enough answers from } \\
\text { academicians to your } \\
\text { questions. }\end{array}$ & 518 & $4,88 \pm 1,63$ & $\begin{array}{l}\text { 1: } 19(3,7 \%) \\
2: 29(5,6 \%) \\
\text { 3: } 62(12 \%) \\
4: 81(15,6 \%) \\
\text { 5: } 116(22,4 \%) \\
\text { 6: } 118(22,8 \%) \\
\text { 7: } 93(18 \%)\end{array}$ & $\begin{array}{l}\text { Female: } \\
4,89 \pm 1,63 \\
\text { Male: } 4,75 \pm 1,63\end{array}$ & 0.44 & $\begin{array}{l}1: 4,66 \pm 1,58 \\
2: 4,98 \pm 1,53 \\
3: 4,77 \pm 1,74 \\
4: 5,22 \pm 1,70 \\
\text { GS: } 5,43 \pm 1,45\end{array}$ & 0.48 \\
\hline
\end{tabular}




\begin{tabular}{|c|c|c|c|c|c|c|c|c|}
\hline Q10 & $\begin{array}{l}\text { Please select the } \\
\text { level of speed of the } \\
\text { response time to } \\
\text { your questions from } \\
\text { academicians. }\end{array}$ & 518 & $4,85 \pm 1,55$ & $\begin{array}{l}\text { 1: } 19(3,7 \%) \\
2: 21(4,1 \%) \\
\text { 3: } 66(12,7 \%) \\
\text { 4: } 72(13,9 \%) \\
\text { 5: } 154(29,7 \%) \\
\text { 6: } 105(20,3 \%) \\
\text { 7: } 81(15,6 \%)\end{array}$ & $\begin{array}{l}\text { Female: } \\
4,87 \pm 1,54 \\
\text { Male: } 4,69 \pm 1,59\end{array}$ & 0.38 & $\begin{array}{l}1: 4,68 \pm 1,41 \\
2: 4,99 \pm 1,55 \\
3: 4,69 \pm 1,73 \\
4: 5,22 \pm 1,39 \\
G S: 5,07 \pm 1,59\end{array}$ & 0.66 \\
\hline Q11 & $\begin{array}{l}\text { Please select your } \\
\text { level of being able } \\
\text { to devote yourself } \\
\text { to online education } \\
\text { exams or homeworks } \\
\text { (your competence to } \\
\text { work efficiently). }\end{array}$ & 518 & $3,88 \pm 1,83$ & $\begin{array}{l}\text { 1: } 63(12,2 \%) \\
\text { 2: } 79(15,3) \\
\text { 3: } 75(14,5) \\
\text { 4: } 106(20,5) \\
\text { 5: } 85(16,4) \\
\text { 6: } 57(\% 11) \\
\text { 7: } 53(\% 10,2)\end{array}$ & $\begin{array}{l}\text { Female: } \\
3,85 \pm 1,80 \\
\text { Male: } 4,02 \pm 2,00\end{array}$ & 0.41 & $\begin{array}{l}1: 3,83 \pm 1,94 \\
2: 3,88 \pm 1,86 \\
3: 3,68 \pm 1,79 \\
4: 4,28 \pm 1,64 \\
G S: 4,36 \pm 1,60\end{array}$ & 0.19 \\
\hline Q12 & $\begin{array}{l}\text { Please select the level } \\
\text { of proficiency of your } \\
\text { time spent on online } \\
\text { education. }\end{array}$ & 518 & $4,08 \pm 1,63$ & $\begin{array}{l}\text { 1: } 28(5,4 \%) \\
\text { 2: } 67(12,9 \%) \\
\text { 3: } 89(17,2 \%) \\
\text { 4: } 137(26,4 \%) \\
\text { 5: } 96(18,5 \%) \\
\text { 6: } 49(9,5 \%) \\
\text { 7: } 52(10 \%)\end{array}$ & $\begin{array}{l}\text { Female: } \\
4,06 \pm 1,61 \\
\text { Male: 4,22 } \pm 1,69\end{array}$ & 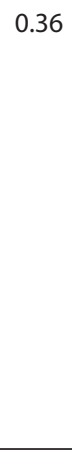 & $\begin{array}{l}1: 3,94 \pm 1,69 \\
2: 4,15 \pm 1,59 \\
3: 4,04 \pm 1,66 \\
4: 4,24 \pm 1,55 \\
\text { GS: } 4,57 \pm 1,40\end{array}$ & 更 \\
\hline Q13 & $\begin{array}{l}\text { Please select the level } \\
\text { of proficiency of the } \\
\text { preparation duration } \\
\text { for homework and } \\
\text { exams. }\end{array}$ & 518 & $4,00 \pm 1,76$ & $\begin{array}{l}\text { 1: } 58(11,2 \%) \\
\text { 2: } 57(11 \%) \\
\text { 3: } 85(16,4 \%) \\
\text { 4: } 95(18,3 \%) \\
\text { 5: } 127(24,5 \%) \\
\text { 6: } 44(8,5 \%) \\
\text { 7: } 52(10 \%)\end{array}$ & $\begin{array}{l}\text { Female: } \\
3,98 \pm 1,73 \\
\text { Male: 4,08 } 1,92\end{array}$ & . & $\begin{array}{l}1: 4,32 \pm 1,62 \\
2: 3,93 \pm 1,84 \\
3: 3,55 \pm 1,86 \\
4: 4,27 \pm 1,57 \\
\text { GS: } 4,57 \pm 1,22\end{array}$ & $0.00^{* * *}$ \\
\hline Q14 & $\begin{array}{l}\text { Please select your } \\
\text { level of readiness to } \\
\text { internship/ work as } \\
\text { Audiologist before the } \\
\text { practical courses are } \\
\text { completed. }\end{array}$ & 518 & $2,54 \pm 1,63$ & $\begin{array}{l}\text { 1: } 200(38,6 \%) \\
\text { 2: } 93(18 \%) \\
\text { 3: } 83(16 \%) \\
\text { 4: } 67(12,9 \%) \\
\text { 5: } 47(9,1 \%) \\
\text { 6: } 17(3,3 \%) \\
\text { 7: } 11(\% 2,1 \%)\end{array}$ & $\begin{array}{l}\text { Female: } \\
2,49 \pm 1,56 \\
\text { Male: } 2,88 \pm 1,98\end{array}$ & 0.30 & $\begin{array}{l}1: 2,41 \pm 1,65 \\
2: 2,19 \pm 1,44 \\
3: 2,36 \pm 1,52 \\
4: 3,67 \pm 1,64 \\
\text { GS: } 4,14 \pm 1,10\end{array}$ & $0.00^{* *}$ \\
\hline
\end{tabular}




\begin{tabular}{|c|c|c|c|c|c|c|c|c|}
\hline Q15 & $\begin{array}{l}\text { Please select your } \\
\text { level of professional } \\
\text { development during } \\
\text { the pandemic period. }\end{array}$ & 518 & $3,11 \pm 1,65$ & $\begin{array}{l}\text { 1: } 99(19,1 \%) \\
\text { 2: } 116(22,4 \%) \\
\text { 3: } 108(20,8 \%) \\
\text { 4: } 87(16,8 \%) \\
\text { 5: } 58(11,2 \%) \\
\text { 6: } 31(6 \%) \\
\text { 7:19 (3,7\%) }\end{array}$ & $\begin{array}{l}\text { Female: } \\
3,10 \pm 1,63 \\
\text { Male: } 3,16 \pm 1,78\end{array}$ & 0.92 & $\begin{array}{l}1: 2,54 \pm 1,63 \\
2: 2,87 \pm 1,76 \\
3: 2,95 \pm 1,54 \\
4: 3,11 \pm 1,60 \\
G S: 3,73 \pm 1,56\end{array}$ & . \\
\hline Q16 & $\begin{array}{l}\text { Please select the } \\
\text { contribution level } \\
\text { of online seminars } \\
\text { held during the } \\
\text { pandemic period to } \\
\text { your professional } \\
\text { development. }\end{array}$ & 518 & $3,72 \pm 1,75$ & $\begin{array}{l}\text { 1: } 65(12,5 \%) \\
\text { 2: } 81(15,6 \%) \\
\text { 3: } 88(17 \%) \\
\text { 4: } 112(21,7 \%) \\
\text { 5: } 81(15,6 \%) \\
\text { 6: } 55(10,6 \%) \\
\text { 7: } 36(6,9 \%)\end{array}$ & $\begin{array}{l}\text { Female: } \\
3,73 \pm 1,74 \\
\text { Male: } 3,58 \pm 1,76\end{array}$ & 0.51 & $\begin{array}{l}1: 3,11 \pm 1,65 \\
2: 3,66 \pm 1,88 \\
3: 3,43 \pm 1,62 \\
4: 3,77 \pm 1,74 \\
\text { GS: 4,18 } 1,69\end{array}$ & 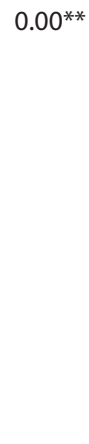 \\
\hline Q17 & $\begin{array}{l}\text { Please select your level } \\
\text { of knowledge about } \\
\text { the precautions that } \\
\text { should be applied } \\
\text { in the clinic during a } \\
\text { pandemic period. }\end{array}$ & 518 & $3,32 \pm 1,72$ & $\begin{array}{l}\text { 1: } 92(17,8 \%) \\
\text { 2: } 93(18 \%) \\
\text { 3: } 110(21,2 \%) \\
\text { 4: } 91(17,6 \%) \\
\text { 5: } 71(13,7 \%) \\
\text { 6: } 33(6,4 \%) \\
\text { 7: } 28(5,4 \%)\end{array}$ & $\begin{array}{l}\text { Female: } \\
3,30 \pm 1,68 \\
\text { Male: } 3,41 \pm 1,91\end{array}$ & 0.73 & $\begin{array}{l}1: 2,74 \pm 1,62 \\
2: 3,03 \pm 1,53 \\
3: 3,58 \pm 1,78 \\
4: 4,36 \pm 1,55 \\
\text { GS: 4,86 } \pm 1,10\end{array}$ & 更 \\
\hline Q18 & $\begin{array}{l}\text { Please select your } \\
\text { level of theoretical } \\
\text { knowledge about Tele- } \\
\text { Audiology services. }\end{array}$ & 518 & $2,94 \pm 1,69$ & $\begin{array}{l}\text { 1: } 138(26,6 \%) \\
\text { 2: } 100(19,3 \%) \\
\text { 3: } 96(18,5 \%) \\
\text { 4: } 79(15,3 \%) \\
\text { 5: } 62(12 \%) \\
\text { 6: } 28(5,4 \%) \\
\text { 7: } 15(2,9 \%)\end{array}$ & $\begin{array}{l}\text { Female: } \\
2,93 \pm 1,67 \\
\text { Male: } 2,98 \pm 1,74\end{array}$ & 0,88 & $\begin{array}{l}1: 2,62 \pm 1,64 \\
2: 2,71 \pm 1,55 \\
3: 3,21 \pm 1,73 \\
4: 3,34 \pm 1,73 \\
G S: 4,21 \pm 1,72\end{array}$ & 更 \\
\hline Q19 & $\begin{array}{l}\text { Please select your } \\
\text { level of practical } \\
\text { competence regarding } \\
\text { Tele-Audiology } \\
\text { services. }\end{array}$ & 518 & $2,64 \pm 1,65$ & $\begin{array}{l}\text { 1: } 173(33,4 \%) \\
\text { 2: } 118(22,8 \%) \\
\text { 3: } 74(14,3 \%) \\
\text { 4: } 85(15,6 \%) \\
\text { 5: } 38(7,3 \%) \\
\text { 6: } 17(3,3 \%) \\
\text { 7: } 17(3,3 \%)\end{array}$ & $\begin{array}{l}\text { Female: } \\
2,61 \pm 1,63 \\
\text { Male: } 2,77 \pm 1,71\end{array}$ & 0,43 & $\begin{array}{l}1: 2,47 \pm 1,73 \\
2: 2,40 \pm 1,47 \\
3: 2,73 \pm 1,59 \\
4: 3,04 \pm 1,73 \\
\text { GS:4,00 } 1,75\end{array}$ & $0.00^{* *}$ \\
\hline
\end{tabular}




\begin{tabular}{|c|c|c|c|c|c|c|c|c|}
\hline Item & $\begin{array}{l}\text { Questions (about } \\
\text { psychological, social } \\
\text { state and career } \\
\text { goals of Audiology } \\
\text { students during the } \\
\text { COVID-19 pandemic } \\
\text { period) }\end{array}$ & $\mathbf{N}$ & $\begin{array}{l}\text { Mean } \pm \text { Std. } \\
\text { Deviation } \\
\text { (Min:1, } \\
\text { not at all; } \\
\text { Max:7, too } \\
\text { much) }\end{array}$ & $\begin{array}{l}\text { Frequency } \\
\text { and Percent- } \\
\text { ages } \\
\text { (Min:1, not at } \\
\text { all; Max:7, too } \\
\text { much }\end{array}$ & $\begin{array}{l}\text { Gender } \\
\text { (Mean } \pm \text { Std. } \\
\text { Deviation) }\end{array}$ & $\begin{array}{l}P \\
\text { Value }\end{array}$ & $\begin{array}{l}\text { Class Degree } \\
\text { (Mean } \pm \text { Std. Devi- } \\
\text { ation) }\end{array}$ & $\begin{array}{l}P \\
\text { Value }\end{array}$ \\
\hline Q20 & $\begin{array}{l}\text { Please select your } \\
\text { level of anxiety that } \\
\text { occurred with the } \\
\text { pandemic period. }\end{array}$ & 518 & $5,53 \pm 1,51$ & $\begin{array}{l}\text { 1: } 10(1,9 \%) \\
\text { 2: } 15(2,9 \%) \\
\text { 3: } 26(5,6 \%) \\
\text { 4: } 68(13,1 \%) \\
\text { 5: } 93(18 \%) \\
\text { 6: } 120(23,2 \%) \\
\text { 7: } 183(35,3 \%)\end{array}$ & $\begin{array}{l}\text { Female: } \\
5,59 \pm 1,47 \\
\text { Male: } 5,08 \pm 1,69\end{array}$ & $0.01^{* *}$ & 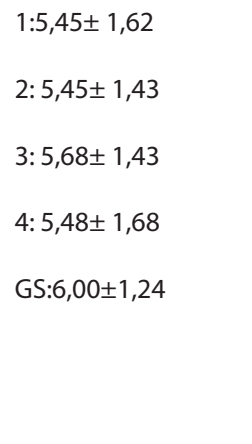 & 更 \\
\hline Q21 & $\begin{array}{l}\text { Please select the level } \\
\text { of psychological, } \\
\text { social and emotional } \\
\text { damage (that will } \\
\text { require help) caused } \\
\text { by this period. }\end{array}$ & 518 & $4,02 \pm 1,87$ & $\begin{array}{l}\text { 1: } 63(12,2 \%) \\
\text { 2: } 70(13,5 \%) \\
\text { 3: } 63(12,2 \%) \\
\text { 4: } 106(20,5 \%) \\
\text { 5: } 96(18,5 \%) \\
\text { 6: } 56(10,8 \%) \\
\text { 7: } 64(12,4 \%)\end{array}$ & $\begin{array}{l}\text { Female: } \\
4,05 \pm 1,86 \\
\text { Male: } 3,75 \pm 1,87\end{array}$ & 0.24 & $\begin{array}{l}1: 3,67 \pm 1,78 \\
2: 3,92 \pm 1,84 \\
3: 4,17 \pm 1,95 \\
4: 4,57 \pm 1,93 \\
G S: 4,43 \pm 1,22\end{array}$ & $0,00^{* *}$ \\
\hline Q22 & $\begin{array}{l}\text { Please select to what } \\
\text { extent the pandemic } \\
\text { process has negatively } \\
\text { affected your social } \\
\text { relationships. }\end{array}$ & 518 & $5,09 \pm 1,74$ & $\begin{array}{l}\text { 1: } 18(3,5 \%) \\
\text { 2: } 37(7,1 \%) \\
\text { 3: } 44(8,5 \%) \\
\text { 4: } 84(16,2 \%) \\
\text { 5: } 80(15,4 \%) \\
\text { 6: } 110(21,2 \%) \\
\text { 7: } 145(28 \%)\end{array}$ & $\begin{array}{l}\text { Female: } \\
5,09 \pm 1,72 \\
\text { Male: } 5,05 \pm 1,85\end{array}$ & 0.94 & $\begin{array}{l}1: 5,15 \pm 1,77 \\
2: 5,23 \pm 1,59 \\
3: 4,99 \pm 1,72 \\
4: 4,99 \pm 1,97 \\
G S: 4,36 \pm 1,98\end{array}$ & 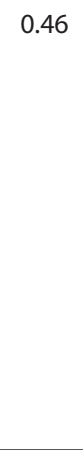 \\
\hline Q23 & $\begin{array}{l}\text { Please select how } \\
\text { well you spend your } \\
\text { free time at home for } \\
\text { your personal-social } \\
\text { development during } \\
\text { the pandemic period. }\end{array}$ & 518 & $3,91 \pm 1,64$ & $\begin{array}{l}\text { 1: } 39(7,5 \%) \\
\text { 2: } 74(14,3 \%) \\
\text { 3: } 91(17,6 \%) \\
\text { 4: } 133(25,7 \%) \\
\text { 5: } 93(18 \%) \\
\text { 6: } 46(8,9 \%) \\
\text { 7: } 42(8,1 \%)\end{array}$ & $\begin{array}{l}\text { Female: } \\
3,88 \pm 1,62 \\
\text { Male: } 4,11 \pm 1,70\end{array}$ & 0.26 & $\begin{array}{l}1: 3,86 \pm 1,73 \\
2: 3,93 \pm 1,60 \\
3: 3,80 \pm 1,59 \\
4: 4,04 \pm 1,60 \\
\text { GS: } 4,86 \pm 1,75\end{array}$ & 0.21 \\
\hline
\end{tabular}




\begin{tabular}{|c|c|c|c|c|c|c|c|c|}
\hline Q24 & $\begin{array}{l}\text { Please select to } \\
\text { what extent the } \\
\text { pandemic period } \\
\text { negatively affected } \\
\text { your professional and } \\
\text { career goals. }\end{array}$ & 518 & $4,68 \pm 1,72$ & $\begin{array}{l}\text { 1: } 23(4,4 \%) \\
\text { 2: } 44(8,5 \%) \\
\text { 3: } 63(12,2 \%) \\
\text { 4: } 93(18 \%) \\
\text { 5: } 117(22,6 \%) \\
\text { 6: } 79(15,3 \%) \\
\text { 7: } 99(19,1 \%)\end{array}$ & $\begin{array}{l}\text { Female: } \\
4,68 \pm 1,70 \\
\text { Male: } 4,61 \pm 1,82\end{array}$ & 0.81 & $\begin{array}{l}1: 4,45 \pm 1,79 \\
2: 4,61 \pm 1,72 \\
3: 4,89 \pm 1,63 \\
4: 5,04 \pm 1,68 \\
\text { GS: } 3,93 \pm 1,69\end{array}$ & 0.26 \\
\hline Q25 & $\begin{array}{l}\text { Please select your level } \\
\text { of satisfaction with the } \\
\text { distance education } \\
\text { period you experience } \\
\text { with the pandemic } \\
\text { process, taking all } \\
\text { factors into account. }\end{array}$ & 518 & $3,52 \pm 1,70$ & $\begin{array}{l}\text { 1: } 76(14,7 \%) \\
\text { 2: } 88(17 \%) \\
\text { 3: } 86(16,6 \%) \\
\text { 4: } 124(23,9 \%) \\
\text { 5: } 78(\% 5,1 \%) \\
\text { 6: } 37(7,1 \%) \\
\text { 7: } 29(5,6 \%)\end{array}$ & $\begin{array}{l}\text { Female: } \\
3,49 \pm 1,66 \\
\text { Male: } 3,66 \pm 1,88\end{array}$ & 0.43 & $\begin{array}{l}1: 3,50 \pm 1,87 \\
2: 3,38 \pm 1,60 \\
3: 3,38 \pm 1,60 \\
4: 3,90 \pm 1,62 \\
\text { GS: 4,71 } \pm 1,64\end{array}$ & 更 \\
\hline Item & $\begin{array}{l}\text { SECOND SECTION } \\
\text { Questions (Only } \\
\text { the 4th grade } \\
\text { students in the } 2020 \\
\text { spring semester } \\
\text { and currently new } \\
\text { graduates) }\end{array}$ & $\mathbf{N}$ & $\begin{array}{l}\text { Mean } \pm \text { Std. } \\
\text { Deviation } \\
\text { (Min:1, too } \\
\text { insufficient; } \\
\text { Max:7, very } \\
\text { sufficient) }\end{array}$ & $\begin{array}{l}\text { Frequency } \\
\text { and Percent- } \\
\text { ages } \\
\text { (Min:1, too } \\
\text { insufficient; } \\
\text { Max:7, very } \\
\text { sufficient) }\end{array}$ & $\begin{array}{l}\text { Gender } \\
\text { (Mean } \pm \text { Std. } \\
\text { Deviation) }\end{array}$ & $\begin{array}{l}\text { P Val- } \\
\text { ue }\end{array}$ & Class Degree & $\begin{array}{l}P \\
\text { Value }\end{array}$ \\
\hline Q26 & $\begin{array}{l}\text { Please select the level } \\
\text { of achieving your } \\
\text { career goals in this } \\
\text { process. }\end{array}$ & 67 & $4,07( \pm 1,63)$ & $\begin{array}{l}\text { 1: } 5(7,5 \%) \\
\text { 2: } 7(10,4 \%) \\
\text { 3: } 10(14,9 \%) \\
\text { 4: } 19(28,4 \%) \\
\text { 5: } 14(20,9) \\
\text { 6: } 6(9 \%) \\
\text { 7: } 6(9 \%)\end{array}$ & $\begin{array}{l}\text { Female: } \\
3,96 \pm 1,61 \\
\text { Male: } 4,70 \pm 1,63\end{array}$ & 0.63 & No analysis. & - \\
\hline Q27 & $\begin{array}{l}\text { Please select } \\
\text { the level of your } \\
\text { knowledge about } \\
\text { what precautions you } \\
\text { need to take in your } \\
\text { workplace (wearing } \\
\text { masks, gloves, social } \\
\text { isolation, etc.) when } \\
\text { you start working. }\end{array}$ & 67 & $6,28( \pm 0,83)$ & $\begin{array}{l}1: 0 \\
2: 0 \\
3: 0 \\
4: 3(4,5 \%) \\
5: 7(10,4 \%) \\
6: 25(37,3 \%) \\
7: 31(47,8 \%)\end{array}$ & $\begin{array}{l}\text { Female: } \\
6,31 \pm 0,78 \\
\text { Male: } 6,10 \pm 1,10\end{array}$ & 0.69 & No analysis. & - \\
\hline
\end{tabular}




\begin{tabular}{|c|c|c|c|c|c|c|c|c|}
\hline Q28 & $\begin{array}{l}\text { Please select the level } \\
\text { of your professional } \\
\text { skills which would } \\
\text { allow you to work as } \\
\text { an audiologist during } \\
\text { pandemic period }\end{array}$ & 67 & $4,19( \pm 1,23)$ & $\begin{array}{l}\text { 1: } 2(3 \%) \\
\text { 2: } 5(7,5 \%) \\
\text { 3: } 10(14,9 \%) \\
\text { 4: } 19(28,4 \%) \\
\text { 5: } 23(34,3 \%) \\
\text { 6: } 8(11,9 \%) \\
\text { 7:0 }\end{array}$ & $\begin{array}{l}\text { Female: } \\
4,17 \pm 1,97 \\
\text { Male: } 4,30 \pm \\
1,49\end{array}$ & 0.12 & No analysis. & - \\
\hline Q29 & $\begin{array}{l}\text { Please select the level } \\
\text { of starting the job you } \\
\text { want as a result of } \\
\text { the job opportunities } \\
\text { affected by this } \\
\text { process. }\end{array}$ & 67 & $3,57( \pm 1,58)$ & $\begin{array}{l}\text { 1: } 10(14,9 \%) \\
\text { 2: } 7(10,4 \%) \\
\text { 3: } 12(17,9 \%) \\
\text { 4: } 19(28,4 \%) \\
\text { 5: } 13(19,4 \%) \\
\text { 6: } 4(6 \%) \\
\text { 7: } 2(3 \%)\end{array}$ & $\begin{array}{l}\text { Female: } \\
3,50 \pm 1,55 \\
\text { Male: } 3,90 \pm 1,72\end{array}$ & 0.51 & No analysis. & - \\
\hline
\end{tabular}

\section{DISCUSSIONS}

In this cross-sectional study, Audiology students' experience in e-learning, Tele-Audiology knowledge and practice, psychological-social status and impact of lack of clinical internships, practical courses and social life on personal development were investigated in the COVID-19 pandemic period.

\section{E-learning System}

Universities in Turkey, like many other countries, have faced difficult decisions on how best to manage Audiology education during the COVID-19 pandemic. Online educational courses were the logical first step in transitioning from traditional education to new alternatives, as instructors and students were wasting time in the unknowns of COVID-19. Determining how to perform the vital portions of Audiology education that require face-to-face interaction including laboratory work and clinical training was a major issue. First, if we look at the general challenges of e-learning systems, we can mention transition to new systems (change), technological factors, e-learning system quality factors, self-efficacy factors, etc. (Almaiah, Al-Khasawneh, \& Althunibat, 2020; Mukhtar, Javed, Arooj, \& Sethi, 2020) The important point is to adopt the system despite these challenges and to acquire theoretical and practical knowledge with this new system. E-learning requires a strong internet connection and easy-to-use programs. Based on the study results, positive answers were obtained in Q1 (infrastructure requirements for e-learning systems such as camera, microphone, internet connection) and Q2 (ease of use in e-learning systems), although students suddenly transition from traditional education to the remote online system. In Table 2, most of the responses of students to the level of knowledge acquired from practical courses were "too insufficient" in the e-learning system. In addition, in Q14, it was revealed that the students regarded themselves as "insufficient" at the level of starting a job as an intern or Audiologist before completing their practical courses and or clinical internships. Results showed that students feel "insufficient" in terms of practical courses and clinical internships with the transition to the e-learning system. A study stated that teaching and learning practical and clinical work as the limit of online education (Mukhtar, Javed, Arooj, \& Sethi, 2020). In addition, other limitations of learning with e-learning can be mentioned as maintaining attention and ensuring interactive participation during the online course. The responses given by the students to the questions about these issues support this. In a survey that ASHA conducted, $100 \%$ of audiology student participants and $98 \%$ of graduate speech-language pathology students showed that the epidemic had a "major" or "moderate" impact on their academic lives. The result in this study was parallel to the Q15 responses in our survey result. Despite the 
challenges brought by the COVID-19 pandemic, we have the opportunity to show our students and future colleagues how we respond to the crisis as a profession. In this period, we can provide a roadmap on how to deal with difficulties based on students' ideas and creativity. Instead of protecting or excluding them because we do not think our current situation provides an ideal learning environment, we should embrace them. We must integrate them into the new system, and we should improve our system for similar situations. They are the future of our profession, and at an important time in our history we have the opportunity to teach them valuable life skills and professionalism that go beyond theoretical and clinical training. With the right protocols and approaches, students can safely return to clinical rotations. Educators can support clinically-based departments such as Audiology with a creative, flexible and sharing approach that includes a case-based education system, tele-practice and compensatory education (Whitelaw, 2020; De Palo et al., 2012; De Palo et al. 2017).

\section{Tele-Audiology}

The COVID-19 pandemic has affected Audiology practice around the world. Therefore, in the era of COVID-19, where social distance and remote services are required, Audiological care services have adapted to this period by using tele-Health and tele-Audiology more frequently (Saunders \& Roughley, 2020; Munoz, Nagaraj \& Nichols, 2020). In one study, 1/3 of the participants stated that they used remote Audiological care services before COVID-19 restrictions, and at the end of the survey, $98 \%$ of the participants reported that they used tele-Audiology during the pandemic (Saunders \& Roughley, 2020). The vast majority (84\%) of them reported that they would continue with tele-Health even after COVID-19 restrictions are over (Saunders \& Roughley, 2020). In another study conducted in Australia, 58\% of Audiologists did not use tele-Audiology services before the pandemic, while $76 \%$ of them used tele-Audiology services after the pandemic (Bennett, Eikelboom, Swanepoel \& Manchaiah, 2020). In literature, while Audiologists have knowledge and perceptions of tele-audiology applications and they share positive attitudes towards teleaudiology, less than $25 \%$ of them have used it in service delivery (Eikelboom \& Swanepoel, 2016; Ravi, Gunjawate, Yerraguntla \& Driscoll, 2018). But, many have concerns about the impact of tele-audiology on hearing healthcare, infrastructure, reimbursement, licensure, etc. (Ravi, Gunjawate, Yerraguntla \& Driscoll, 2018; Singh, Pichora-Fuller, Malkowski, Boretzki \& Launer, 2014). After the necessity of stopping many appointments for a while due to the COVID-19 pandemic, it became necessary to identify patients in critical periods and be treated before it is too late (Thai-Van et al., 2020). In this case, tele-Audiology allows these patients not to miss the critical period and it is important to know best practice (Thai-Van et al., 2020). In difficult situations such as a pandemic, tele-Audiology is important for the continuity of the service, especially for people from all social strata (Swanepoel \& Hall III, 2010). Thus, it should be included in the Audiology education program for the most accurate applications in tele-Audiology. In Table 2, the answers given in the questionnaire regarding the theoretical knowledge level and practical competency of tele-Audiology (Q18, Q19) seem "too insufficient". In this case, it shows that the Audiology students should be educated urgently on knowledge and practice of Tele-Audiology.

\section{Psychological and Social Status}

In order to prevent the spread of the COVID-19 pandemic, the social distance and quarantine rules have made distance education compulsory. University students spent the pandemic process mostly in their families' homes. In addition to stress factors such as health problems and fear of losing loved ones, university students often faced stay-at-home orders. Recent research highlights the psychological effects of COVID-19 on university students (Xiong et al., 2020). Many of them feel increased levels of stress and anxiety and depressive symptoms as a result of the changing service and uncertainty of university education, technological concerns of online courses, stay-at-home restrictions, social isolation, decreased family income, and future employment (Xiong et al., 2020). These different factors have been researched and observed in higher education students all over the world (Aristovnik, Kerzic, Ravšelj, Tomazevic \& Umek, 2020). According to the global study, one of the groups strongly affected is applied sciences students (Aristovnik, Kerzic, Ravšelj, Tomazevic \& Umek, 2020). In our study, the majority of the Audiology students (35.3\%) indicated the level of anxiety developed with the COVID-19 pandemic as "too much". In the literature, 
the study, examining the experiences of students in 62 countries, reported that students expressed concerns about their academic and professional careers, as well as boredom, anxiety and disappointment (Aristovnik, Kerzic, Ravšelj, Tomazevic \& Umek, 2020). In addition, another similar study conducted in China reported increased anger, sadness, anxiety and fear in students (Cao et al., 2020). Another study also showed that the majority of participants experienced changes in their social relationships with family and friends due to limited physical interactions (Son, Hegde, Smith, Wang \& Sasangohar, 2020). In our findings, in Table 2, many of the students showed that their anxiety increased during this period and their social relations were seriously affected. Increased anxiety, social isolation, and lack of a clear treatment protocol for COVID-19 naturally negatively affect students' psychology, social relationships and emotions. When all factors were evaluated, students' satisfaction was also obtained as negative in this period, as seen in Table 2, Q25.

\section{Personal Development}

Students' responses about personal development are not surprising, as the motivation and variety of activities that students need for their professional development decreased in this period. The responses showed that the majority of students could not improve themselves effectively professionally during the pandemic period. Being able to organize their free time also plays a critical role in the personal development of the students during this period. The fact that students spend more time in the e-learning system than the face-to-face education period may have disturbed this balance. It may be difficult for students who already have limited social interaction to take care and make efforts for their personal and professional development. In the literature, a global study revealed that during quarantine students "most of the time" or "all of the time" were concerned about their future professional career and examined topics such as lectures, seminars and practical work (Aristovnik, Kerzic, Ravšelj, Tomazevic \& Umek, 2020). Our study also supports the negative effect of the COVID-19 pandemic with the results of students to personal and professional development questions. University students who are an important part of the community could adopt behavior modification to COVID-19 outcomes by adopting new behaviors such as healthy diet, practicing meditation, learning to dance, watching videos, series, movies, games, and attending online scientific seminars (Mukhtar, 2020). In another study, it was concluded that reading books during the isolation process or learning a musical instrument contributed to their personal development. They gave importance to their courses or they prepared for various exams and increased their communication with their families (Akyol, Baskan \& Baskan, 2020).

\section{CONCLUSION}

The primary goal of our research was to shed light on the impact of the COVID-19 crisis on the lives of Audiology students and the need to support students. The main result of this research is that students experience the negative effects of the COVID-19 pandemic in many ways. The study concluded that students experienced dissatisfaction with the e-learning used as a result of restrictions. In an applied department such as Audiology, the COVID-19 pandemic may lead to gaps in education. These shortcomings should be compensated, especially at the point of practical courses and internships. There is a need for effective support, guidance and good management of the process. In addition, in order to implement remote Audiological services/ tele-Audiology in situations such as pandemics, tele-Audiology education should be more focused during the undergraduate and graduate education periods. Our study revealed a serious gap in this issue.

Our research results supported the fact that the courses of tele-audiology and its applications should be included in the curriculum of the audiology students during their education. The needs of students resulting from the interruption of face-to-face clinical internships due to the COVID-19 pandemic can be determined through studies, and alternative methods such as virtual internship practices can be applied to meet the needs of students. In addition, it is important to investigate whether virtual programs are effective for clinical internship practices in order to reduce the problems that may be encountered in the upcoming period. New graduates can be supported in their career planning with career planning services, which include analysis by experts on changes in job opportunities due to the pandemic. In addition, seminars can be organized for success in business life in this process for new graduates. These groups affected by this period in terms of educational competence can be monitored continuously, follow-up studies and activities related to their needs can be organized in the ongoing process. 
Methods should be developed to increase the personal attention and internal motivation of students in online education (e.g. game-based learning platforms can be used) for the current pandemic period and similar situations that may occur in the future. Institutional online activities and services can be implemented to help eliminate the anxiety caused by the absence of social activities (cinema, theater, concerts) and the quarantine process in pandemic conditions (e.g. virtual film festivals, virtual group exercises, etc.).

Future studies can be developed with the participation of more universities and more students from different countries, and follow-up studies can be carried out in the ongoing COVID-19 process.

\section{LIMITATIONS OF THE STUDY}

Some limitations are pointed out in this study. The participation of a small number of graduate students can be seen as a limitation of the study. In cooperation with universities that provide audiology education in other countries, joint surveys can be conducted on this subject. In this study, the high levels of stress and anxiety may be related to the execution of the coronavirus quarantine immediately after its onset. It is possible that, over time, amid the coronavirus quarantine, the ability to cope with stress and anxiety will gradually decrease as students become accustomed to this situation. Therefore, after a certain interval (about 3 months), we could apply the survey again to the participants who participated in the survey. Finally, we did not examine how student mental health problems differ in respect to personal and social contexts (e.g. income, religion, habits).

\section{BIODATA and CONTACT ADDRESSES of AUTHORS}

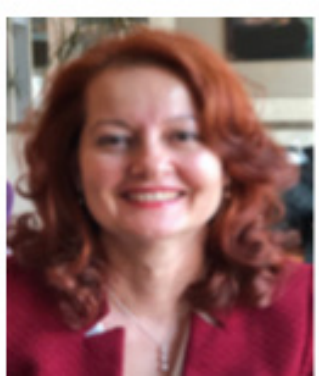

Dr. Gul OLCEK works as an Assistant Professor at Department of Audiology, Faculty of Health Sciences, Istanbul Medipol University. She received her graduate degrees (PhD in 2008) from Marmara University, Department of Otolaryngology, Audiology and Speech Disorders Program. She gained her undergraduate degree in Physical Therapy and Rehabilitation from Hacettepe University. Her academic interest areas are tele-audiology, pediatric and geriatric audiology, vestibular diseases, genetics and electrophysiological methods. She has articles and presentations on these topics.

\section{Gul OLCEK}

Department of Audiology, Faculty of Health Sciences

Address: Istanbul Medipol University, Istanbul, Turkey

Phone: 4448544

E-mail: golcek@medipol.edu.tr / gul.olcek7@gmail.com

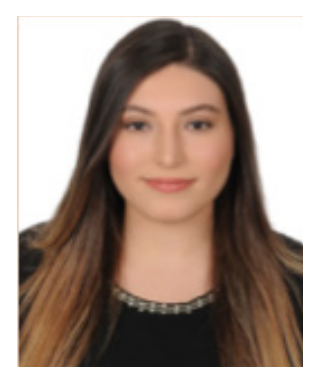

Ilayda CELIK is Research Assistant at Department of Speech and Language Therapy, Faculty of Health Sciences, Istanbul Atlas University. She is also Ph.D. student at Department of Speech and Language Therapy, Graduate School of Health Sciences, Istanbul Medipol University. She gained her undergraduate degrees in Speech and Language Therapy and Audiology, her M.Sc. degree in Clinical Audiology. Her academic interest areas are tele-audiology, audiology, speech and language disorders, electrophysiology, vestibular diseases and speech perception. She has articles and presentations on these topics.

Ilayda CELIK

Department of Speech and Language Therapy, Faculty of Health Sciences

Address: Istanbul Atlas University, Istanbul, Turkey

Phone: 4443439

E-mail: ilayda.celik@atlas.edu.tr / milaydacelikk@gmail.com 


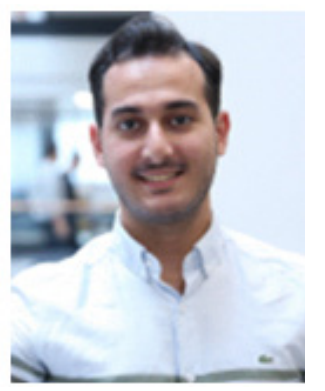

Yusa BASOGLU is Research Assistant at Department of Audiology, Faculty of Health Sciences, Istanbul Medipol University. He is also Ph.D. student at Department of Audiology, Graduate School of Health Sciences, Istanbul Medipol University. He gained his undergraduate degree in the field of Audiology, his M.Sc. degree in Clinical Audiology. His academic interest areas are tele-audiology, audiology, vestibular system, vestibular diseases, vestibular rehabilitation, virtual reality, electrophysiology and hearing aids/cohlear implant. He has articles and presentations on these topics.

Yusa BASOGLU

Department of Audiology, Faculty of Health Sciences

Address: Istanbul Medipol University, Istanbul, Turkey

Phone: 4448544

E-mail: ybasoglu@medipol.edu.tr

\section{REFERENCES}

Abbasi, M. S., Ahmed, N., Sajjad, B., Alshahrani, A., Saeed, S., Sarfaraz, S., Alhamdan, R. S., Vohra, F., \& Abduljabbar, T. (2020). E-Learning perception and satisfaction among health sciences students amid the COVID-19 pandemic. Work (Reading, Mass.), 67(3), 549-556.

Abbasi, S., Ayoob, T., Malik, A., \& Memon, S. I. (2020). Perceptions of students regarding E-learning during Covid-19 at a private medical college. Pakistan journal of medical sciences,36 (COVID19S4),S57-S61.

Altinyay S., (2020). COVID-19 Salgin Donemi: Odyolojide Tele-Mudahale Uygulamalari. Turkiye Klinikleri, 48-52.

Akkermans, J., Richardson, J., \& Kraimer, M. L. (2020). The Covid-19 crisis as a career shock: Implications for careers and vocational behavior. Journal of Vocational Behavior, 119, 103434.

Akyol, G., Baskan, A. H., \& Baskan, A. H. (2020). Yeni tip koronavirus (Covid-19) doneminde spor bilimleri fakultesi ogrencilerinin karantina zamanlarinda yaptiklari etkinlikler ve sedanter bireylere onerileri. Avrasya Sosyal ve Ekonomi Arastirmalari Dergisi, 7(5), 190-203.

AlAteeq, D. A., Aljhani, S., \& AlEesa, D. (2020). Perceived stress among students in virtual classrooms during the COVID-19 outbreak in KSA. Journal of Taibah University Medical Sciences, 15(5), 398-403.

Almaiah, M. A., Al-Khasawneh, A., \& Althunibat, A. (2020). Exploring the critical challenges and factors influencing the E-learning system usage during COVID-19 pandemic. Education and Information Technologies, 25, 5261-5280.

Araujo, F., de Lima, L., Cidade, P., Nobre, C. B., \& Neto, M. (2020). Impact Of Sars-Cov-2 And Its Reverberation. In Global Higher Education And Mental Health. Psychiatry research, 288, 112977.

Aristovnik, A., Kerzic, D., Ravšelj, D., Tomazevic, N., \& Umek, L. (2020). Impacts of the COVID-19 pandemic on life of higher education students: A global perspective. Sustainability, 12(20), 8438.

ASHA Staff (June 9, 2020) COVID-19 Impact on ASHA Members: The Personal and the Professional. ASHA surveyed members in March and May about top challenges, telepractice experiences, and how the pandemic changed their lives. Retrieved December 25, 2020 from https://leader.pubs.asha.org/ do/10.1044/leader.AAG.25062020.28/full/.

Baczek, M., Zaganczyk-Baczek, M., Szpringer, M., Jaroszynski, A., \& Wożakowska-Kapłon, B. (2021). Students' perception of online learning during the COVID-19 pandemic: A survey study of Polish medical students. Medicine, 100(7), e24821.

Baticulon, R. E., Sy, J. J., Alberto, N. R. I., Baron, M. B. C., Mabulay, R. E. C., Rizada, L. G. T., ... \& Reyes, J. C. B. (2021). Barriers to online learning in the time of COVID-19: A national survey of medical students in the Philippines. Medical science educator, 1-12. 
Beaunoyer, E., Dupere, S., \& Guitton, M.J. (2020). COVID-19 and digital inequalities:Reciprocal impacts and mitigation strategies. Computers in Human Behavior, 111, 106424.https://doi.org/10.1016/j. chb.2020.106424.

Bennett, R., Eikelboom, R., Swanepoel, D., \& Manchaiah, V. (2020). Tele-Audiology Services In Australia: A Shift In Clinical Practices.

Browning, M. H., et al. (2021). Psychological impacts from COVID-19 among university students: Risk factors across seven states in the United States. PloS one, 16(1), e0245327.

Cao, W., Fang, Z., Hou, G., Han, M., Xu, X., Dong, J., \& Zheng, J. (2020). The psychological impact of the COVID-19 epidemic on college students in China. Psychiatry Research, 287, 112934.

Chaturvedi, K., Vishwakarma, D. K., \& Singh, N. (2021). COVID-19 and its impact on education, social life and mental health of students: A survey. Children and youth services review, 121, 105866.

Choi, B., Jegatheeswaran, L., Minocha, A., Alhilani, M., Nakhoul, M., \& Mutengesa, E. (2020). The impact of the COVID-19 pandemic on final year medical students in the United Kingdom: a national survey. BMC medical education, 20(1), 1-11.

Cortina, J. M. (1993). What is coefficient alpha? An examination of theory and applications. Journal of Applied Psychology, 78(1), 98-104.

De Palo, V., Sinatra, M., Tanucci, G., Monacis, L., Di Bitonto, P., Roselli, T., Rossano, V. (2012) How cognitive styles affect the e-learning process, Proceedings of the 12th IEEE International Conference on Advanced Learning Technologies, ICALT 2012, art. no. 6268119, pp. 359-363.

De Palo, V., Monacis, L., Miceli, S., Sinatra, M., Di Nuovo, S. (2017) Decisional procrastination in academic settings: The role of metacognitions and learning strategies, Frontiers in Psychology, 8, art. no. 973.

Doyumgac, I., Tanhan, A., \& Kiymaz, M. S. (2021). Understanding the Most Important Facilitators and Barriers for Online Education during COVID-19 through Online Photovoice Methodology. International Journal of Higher Education, 10(1), 166-190.

Elmer, T., Mepham, K., \& Stadtfeld, C. (2020). Students under lockdown: Comparisons of students' social networks and mental health before and during the COVID-19 crisis in Switzerland. PloS one, 15(7), e0236337.

Eikelboom, R. H., \& Swanepoel, D. W. (2016). International survey of audiologists' attitudes toward telehealth. American Journal of Audiology, 25(3S), 295-298.

Education, Audiovisual and Culture Executive Agency (April 2, 2020). How is COVID-19 affecting schools in Europe?. Retrived December 25, 2020 from https://eacea.ec.europa.eu/erasmus-plus/news/howcovid-19-affecting-schools-in-europe_en.

Gokdogan C, Genc A. COVID-19 salgini doneminde odyolojide ogrenci egitimi. Kemaloglu YK, editor. Koronavirus Hastaligi 2019 (COVID-19) ve Isitme Yetersizliginden Etkilenmis Bireylere Yonelik Uygulamalar (Otoloji/Otonoroloji, Odyoloji ve Ozel Egitim). 1. Baski. Ankara: Turkiye Klinikleri; 2020. p.1-4.

Grogan-Johnson, S., Meehan, R., McCormick, K., \& Miller, N. (2015). Results of a national survey of preservice telepractice training in graduate speech-language pathology and audiology programs. Contemporary Issues in Communication Science and Disorders, 42(Spring), 122-137.

Händel, M., Stephan, M., Gläser-Zikuda, M., Kopp, B., Bedenlier, S., \& Ziegler, A. (2020). Digital readiness and its effects on higher education students' socio-emotional perceptions in the context of the COVID-19 pandemic. Journal of Research on Technology in Education, 1-13.

Ibrahim, N. K., Al Raddadi, R., AlDarmasi, M., Al Ghamdi, A., Gaddoury, M., AlBar, H. M., \& Ramadan, I. K. (2021). Medical students' acceptance and perceptions of e-learning during the Covid-19 closure time in King Abdulaziz University, Jeddah. Journal of infection and public health, 14(1), 17-23.

Liu, J., Zheng, X., Tong, Q., Li, W., Wang, B., Sutter, K., Trilling, M., Lu, M., Dittmer, U., \& Yang, D. (2020). Overlapping and discrete aspects of the pathology and pathogenesis of the emerging human pathogenic coronaviruses SARS-CoV, MERS-CoV, and 2019-nCoV. Journal of Medical Virology, 92(5), 491-494. 
Miller, G. (2020). Social distancing prevents infections, but it can have unintended consequences. Science. Advance online publication. https://doi.org/10.1126/science.abb7506

Mohan, H. S., Anjum, A., \& Rao, P. (2017). A Survey of Telepractice in Speech-Language Pathology and Audiology in India. International journal of telerehabilitation, 9(2), 69-80. https://doi.org/10.5195/ ijt.2017.6233

Mukhtar, K., Javed, K., Arooj, M., \& Sethi, A. (2020). Advantages, Limitations and Recommendations for online learning during COVID-19 pandemic era. Pakistan Journal of Medical Sciences, 36(COVID19-S4), S27.

Mukhtar, S. (2020). Pakistanis' mental health during the COVID-19. Asian Journal of Psychiatry.

Munoz, K., Nagaraj, N. K., \& Nichols, N. (2020). Applied tele-audiology research in clinical practice during the past decade: a scoping review. International Journal of Audiology, 1-9.

Pascarella, G., Strumia, A., Piliego, C., Bruno, F., Del Buono, R., Costa, F., Scarlata, S., \& Agro, F. E. (2020). COVID-19 diagnosis and management: a comprehensive review. Journal of Internal Medicine, 288(2), 192-206.

Rahiem, M. D. (2020). The emergency remote learning experience of university students in indonesia amidst the COVID-19 crisis. International Journal of Learning, Teaching and Educational Research, 19(6), 1-26.

Ravi, R., Gunjawate, D. R., Yerraguntla, K., \& Driscoll, C. (2018). Knowledge and perceptions of teleaudiology among audiologists: A systematic review. Journal of Audiology \& Otology, 22(3), 120.

Richardson, J. C., Maeda, Y., Lv, J., \& Caskurlu, S. (2017). Social presence in relation to students' satisfaction and learning in the online environment: A meta-analysis. Computers in Human Behavior, 71, 402-417.

Rizun, M., \& Strzelecki, A. (2020). Students' acceptance of the Covid-19 impact on shifting higher education to distance learning in Poland. International Journal of Environmental Research and Public Health, 17(18), 6468.

Rogowska, A. M., Kuśnierz, C., \& Bokszczanin, A. (2020). Examining anxiety, life satisfaction, general health, stress and coping styles during COVID-19 pandemic in Polish sample of university students. Psychology Research and Behavior Management, 13, 797.

Saunders, G. H., \& Roughley, A. (2020). Audiology in the time of COVID-19: practices and opinions of audiologists in the UK. International Journal of Audiology, 1-8.

Sundarasen, S., Chinna, K., Kamaludin, K., Nurunnabi, M., Baloch, G. M., Khoshaim, H. B., Hossain, S., \& Sukayt, A. (2020). Psychological Impact of COVID-19 and Lockdown among University Students in Malaysia: Implications and Policy Recommendations. International journal of environmental research and public health, 17(17), 6206.

Singh, G., Pichora-Fuller, M. K., Malkowski, M., Boretzki, M., \& Launer, S. (2014). A survey of the attitudes of practitioners toward teleaudiology. International Journal of Audiology, 53(12), 850-860.

Son, C., Hegde, S., Smith, A., Wang, X., \& Sasangohar, F. (2020). Effects of COVID-19 on college students' mental health in the United States: Interview survey study. Journal of Medical Internet Research, 22(9), e21279.

Swanepoel, D. W., Clark, J. L., Koekemoer, D., Hall Iii, J. W., Krumm, M., Ferrari, D. V, McPherson, B., Olusanya, B. O., Mars, M., Russo, I., \& others. (2010). Telehealth in audiology: The need and potential to reach underserved communities. International Journal of Audiology, 49(3), 195-202.

Swanepoel, D. W., \& Hall III, J. W. (2010). A systematic review of telehealth applications in audiology. Telemedicine and E-Health, 16(2), 181-200.

Thai-Van, H., Bakhos, D., Bouccara, D., Loundon, N., Marx, M., Mom, T., Mosnier, I., Roman, S., Villerabel, C., Vincent, C., \& others. (2020). Telemedicine in Audiology. Best practice recommendations from the French Society of Audiology (SFA) and the French Society of Otorhinolaryngology-Head and Neck Surgery (SFORL). European Annals of Otorhinolaryngology, Head and Neck Diseases.

TR Ministry of Health COVID-19 Information Page. (2020). Retrieved December 20, 2020 from https:// covid19.saglik.gov.tr/ 
Volkers, N. What COVID-19 Teaches about Online Learning; American Speech-Language-Hearing Association: Rockville, MD, USA, 2020; pp. 47-55.

Wang, C., Xie, A., Wang, W., \& Wu, H. (2020). Association between medical students' prior experiences and perceptions of formal online education developed in response to COVID-19: a cross-sectional study in China. BMJ open, 10(10), e041886.

Whitelaw, G. M. (2020). Audiology Education Amid COVID-19. The Hearing Journal, 73(5), 8-9.

Wootton, R., \& others. (2009). The future use of telehealth in the developing world. The Royal Society of Medicine Press Internacional Development Research.

Xiong, J., Lipsitz, O., Nasri, F., Lui, L. M. W., Gill, H., Phan, L., Chen-Li, D., Iacobucci, M., Ho, R., Majeed, A., \& others. (2020). Impact of COVID-19 pandemic on mental health in the general population: A systematic review. Journal of Affective Disorders, 275, 54-55.

Zolotov, Y., Reznik, A., Bender, S., \& Isralowitz, R. (2020). COVID-19 fear, mental health, and substance use among Israeli university students. International journal of mental health and addiction, 1-7. 